\title{
Northern Florida reef tract benthic metabolism scaled by remote sensing
}

\author{
John C. Brock ${ }^{1, *}$, Kimberly K. Yates ${ }^{1}$, Robert B. Halley ${ }^{1}$, Ilsa B. Kuffner ${ }^{1}$, \\ C. Wayne Wright ${ }^{2}$, Bruce G. Hatcher ${ }^{3}$ \\ ${ }^{1}$ U.S. Geological Survey, Center for Coastal and Watershed Studies, 600 4th Street South, St. Petersburg, Florida 33701, USA \\ ${ }^{2}$ NASA Goddard Space Flight Center, Wallops Flight Facility, Wallops Island, Virginia 23337, USA \\ ${ }^{3}$ University College of Cape Breton, 1250 Grand Lake Road, Sydney, Nova Scotia B1P 6L2, Canada
}

\begin{abstract}
Holistic rates of excess organic carbon production $(E)$ and calcification for a $0.5 \mathrm{~km}^{2}$ segment of the backreef platform of the northern Florida reef tract (NFRT) were estimated by combining biotope mapping using remote sensing with community metabolic rates determined with a benthic incubation system. The use of ASTER multispectral satellite imaging for the spatial scaling of benthic metabolic processes resulted in errors in $E$ and net calcification $(G)$ of 48 and $431 \%$ respectively, relative to estimates obtained using AISA hyperspectral airborne scanning. At 19 and $125 \%$, the $E$ and $G$ errors relative to the AISA-based estimates were less pronounced for an analysis that used IKONOS multispectral satellite imagery to spatially extrapolate the chamber process measurements. Our scaling analysis indicates that the holistic calcification rate of the backreef platform of the northern Florida reef tract is negligible at $0.07 \mathrm{~g} \mathrm{CaCO}_{3} \mathrm{~m}^{-2} \mathrm{~d}^{-1}$. All of the mapped biotopes in this reef zone are net heterotrophic, resulting in an estimated holistic excess production rate of $-0.56 \mathrm{~g} \mathrm{C} \mathrm{m}^{-2} \mathrm{~d}^{-1}$, and an overall gross primary production to respiration ratio of 0.85 . Based on our finding of ubiquitous heterotrophy, we infer that the backreef platform of the NFRT is a sink for external inputs of suspended particulate organic matter. Further, our results suggest that the inward advection of inorganic nutrients is not a dominant forcing mechanism for benthic biogeochemical function in the NFRT. We suggest that the degradation of the northern Florida reef tract may parallel the community phase shifts documented within other reef systems polluted by organic detritus.
\end{abstract}

KEY WORDS: Coral reefs $\cdot$ Benthic metabolism $\cdot$ Remote sensing $\cdot$ Lidar $\cdot$ Northern Florida reef tract

\section{INTRODUCTION}

Meaningful stewardship of coral reef tracts requires new capabilities for the rigorous, broad spatial evaluation of these ecosystems, and for the advanced prediction of their alteration due to anthropogenic stress combined with change in the global environment (Hatcher 1997). Holistic and quantitative methods that enable timely and geographically detailed appraisals of pollution effects or generalized endemic stress on coral reefs are not available at present (Grigg \& Dollar 1990, Wilkinson 1992). Existing monitoring methods based on population inventories, sclerochronology, or reproductive biology are of great value, but are geo- graphically constrained, and may provide inconsistent results due to sampling bias (Brown 1988). Synoptic techniques that can be implemented with efficiency are required to discern incipient sub-lethal effects that may cause long-term increases in coral mortality (Brown 1988, Grigg \& Dollar 1990). The capability to recognize differences in ecosystem structure and biogeochemical function between pristine and degraded reefs could inform and direct science-based management (Done 1992).

In situ measurement of coral reef community metabolism can be used to assess reef health as impacted by changes in environmental parameters such as grazing, sedimentation, eutrophication (Gattuso \& Jaubert 
1990), storm frequency (Done 1999), and atmospheric carbon-dioxide concentration (Kleypas et al. 1999). The spatial scale of carbon and carbonate flux measurements across a coral reef ecosystem is variable (Gattuso et al. 1998). Therefore, the inclusion of detailed ecosystem structure is difficult if strictly in situ methods are used in scaling-up the investigation of reef metabolism from the organism to the community and landscape levels (Andrefouet \& Payri 2000).

Remote sensing methods provide a synoptic, repeatable, and multiple-scale view of the biosphere, but at the present time the direct sensing of benthic metabolic rates is not possible. Joyce \& Phinn (2003) examined the relation between spectral reflectance, chlorophyll a concentration, and photosynthetic capacity for common coral reef substrates. They found that photosynthetic capacity did not exhibit statistically significant correlations to spectral reflectance or absorption at any wavelength for massive corals, macroalgae, and sediment interspersed with benthic microalgae. However, if coupled with process measurements or models, satellite and airborne imaging is of great value in investigating biogeochemical fluxes across a range of spatial scales (Gurney et al. 1993). Direct remote sensing of the reef system landscape (Andrefouet et al. 2001, Bouvet et al. 2003) and community structure (Clark et al. 1997, Mumby et al. 1997a, 1998) and the indirect remote sensing of environmental conditions (Green et al. 2000) provides a method for the geographic extrapolation of in situ point measurements (Yates \& Halley 2003).

Models of the organic carbon and carbonate metabolism of coral reef ecosystems, parameterized by process measurements and scaled in time-space using remote sensing, can integrate studies of physical and chemical forcing with observed biological and geological responses (Grigg et al. 1984, Hatcher 1999). Synoptic geographical modeling of reef biogeochemical dynamics has potential for the prediction of coral reef change across a range of time scales (Hatcher 1997, Andrefouet \& Payri 2000). Such prediction of coral reef responses to environmental forcing scenarios on the ecosystem scale has been suggested as the only meaningful approach to preserve coral reefs (Bohnsack \& Ault 1996, Christensen et al. 1996).

This paper presents the initial development of a model of coral reef benthic ecosystem carbon and carbonate fluxes that is scaled geographically through the use of remote mapping sensors mounted on aircraft and satellites. The analyses presented are limited to an approximately $0.5 \mathrm{~km}^{2}$ segment of a single reef zone, the patch reef-studded platform of the northern Florida reef tract (NFRT) within Biscayne National Park. The objectives are to: (1) Test the influence of variable mapping sensor accuracies on the estimation of the space-scaled metabolism; (2) Determine the interbiotope variability of benthic carbon and carbonate metabolism within this reef zone; and (3) Use a holistic estimate of reef platform biogeochemical performance to examine the net impact of combined natural and human stresses on the NFRT.

\section{MATERIALS AND METHODS}

The study area is located approximately $5 \mathrm{~km}$ east of Caesar's Creek and Elliot Key on the lagoonal carbonate platform seaward of Hawk Channel in the NFRT within Biscayne National Park (Fig. 1) (Ginsburg \& Shinn 1993). This backreef platform lies landward of Ajax Reef, a shelf-edge bank reef, and is covered by carbonate sand, mostly capped by a Thalassia testudinum seagrass meadow and numerous scattered patch

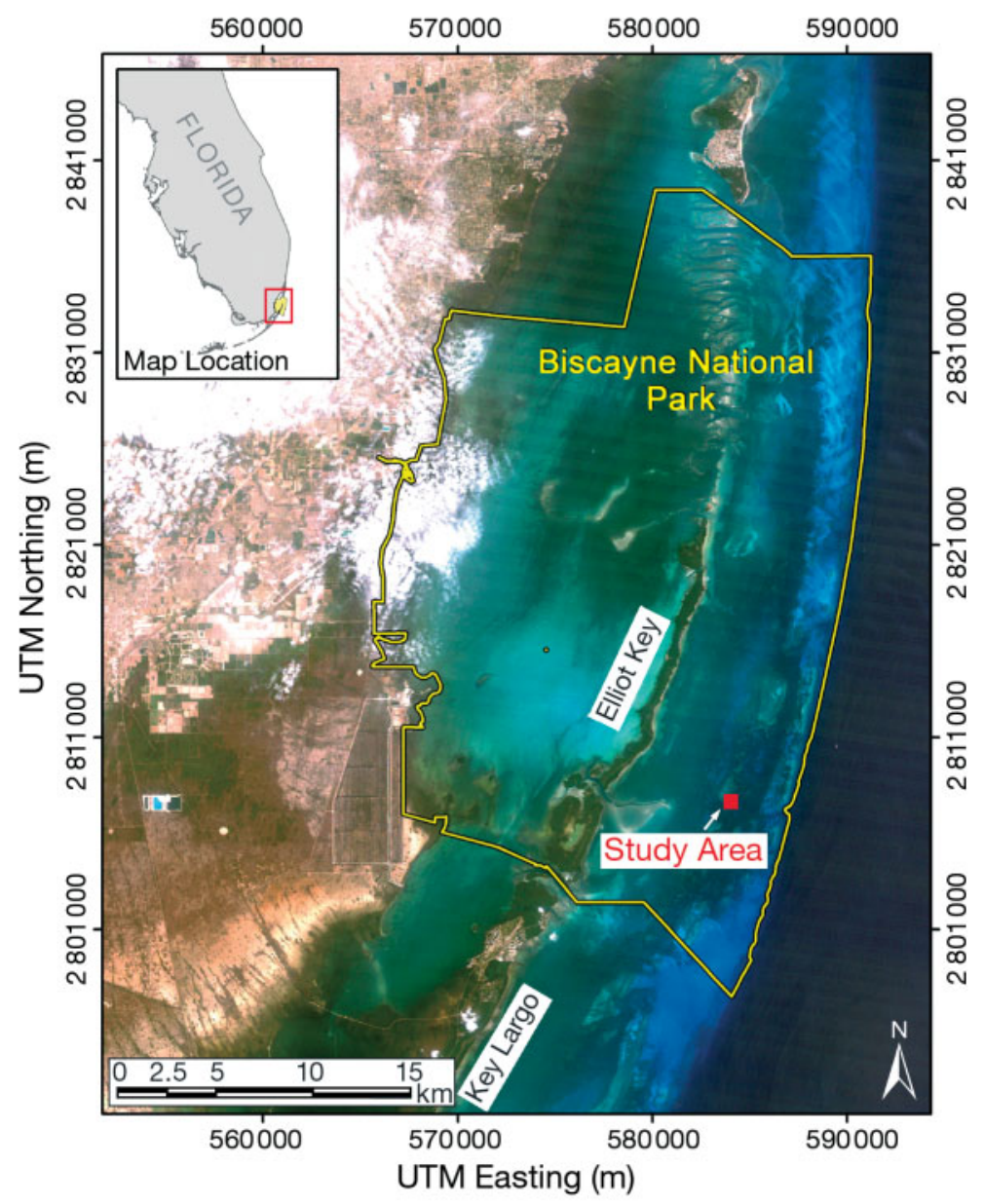

Fig. 1. Study area location shown on a Landsat satellite image. UTM: universal transverse Mercator 
Table 1. Sensor design and acquisition specifications

\begin{tabular}{|c|c|c|c|c|}
\hline & EAARL & AISA & IKONOS & ASTER \\
\hline Platform & Aircraft & Aircraft & Satellite & Satellite \\
\hline Altitude (m) & 300 & 1500 & 681000 & 705000 \\
\hline Acquisition date & Jul-Aug 2001, Aug 2002 & Jan 7, 2001 & Mar 18, 2001 & Jan 31, 2001 \\
\hline Horizontal resolution (m) & $\sim 1$ & 1.5 & 4 & 15 \\
\hline Vertical resolution $(\mathrm{cm})$ & $\sim 20$ & NA & NA & NA \\
\hline Spot density (No. of spots $\mathrm{m}^{-2}$ ) & $\sim 1$ & NA & NA & NA \\
\hline Ground spot diameter (cm) & $\sim 20$ & NA & NA & NA \\
\hline $\begin{array}{l}\text { Number of spectral bands } \\
(400 \text { to } 700 \mathrm{~nm})\end{array}$ & 1 (532 nm laser) & 25 & $\begin{array}{l}3 \\
\# 1: 450-520 \mathrm{~nm} \\
\# 2: 520-600 \mathrm{~nm} \\
\# 3: 630-690 \mathrm{~nm}\end{array}$ & $\begin{array}{l}2 \\
\# 1: 520-600 \mathrm{~nm} \\
\# 2: 630-690 \mathrm{~nm}\end{array}$ \\
\hline Spectral band width (nm) & NA & $10 \mathrm{~nm}$ & $60-80 \mathrm{~nm}$ & $60-80 \mathrm{~nm}$ \\
\hline
\end{tabular}

reefs surrounded by bare sandy halos (Shinn et al. 1989, McPherson \& Halley 1996). The patch reefs are roughly circular, with a maximum vertical relief of about $3 \mathrm{~m}$ and a breadth of $10 \mathrm{~m}$ to $100 \mathrm{~m}$, and mostly occur in coalesced groups in the north and west portions of the study area. At present, octocorals dominate the topographically irregular tops of these patch reefs, above a framework of scleractinian corals that grew upward as sea-level rose during the Holocene transgression (Jones 1963, 1977, Marszalek et al. 1977, Jaap 1984, Shinn et al. 1989).

Most earlier studies of reef metabolism have focused on pristine reef systems in the western Pacific, leading to the conclusion that rates of coral reef carbon and carbonate production conform narrowly to standard modes (Kinsey 1983, 1985). In contrast, we selected a site that is at the downstream end of the general circulation in both the Caribbean region and the Florida reef tract and adjacent to the heavily urbanized coastal region around Miami (Burke \& Maidens 2002). We chose a study site that is located to reflect, in metabolic performance, the degradation of coral reefs that is well recognized throughout the Caribbean (Hallock et al. 1993) and within the Florida reef tract (Causey et al. 2002a). Our study site is impacted by cold-water disturbances (Burns 1985), frequent hurricanes, coral diseases (Mueller et al. 2001, Porter et al. 2001), overfishing (Ault et al. 1998), bleaching (Hoegh-Guldberg 1999), and pollution (Jones \& Boyer 2001). We view our study site on the backreef platform of the NFRT as an excellent location for examining the metabolism of a stressed and degraded reef system.

Remote sensing observations. The Advanced Imaging Spectrometer for Applications (AISA) sensor (Table 1) was flown at an altitude of approximately $1500 \mathrm{~m}$ on January 7, 2001 to collect hyperspectral imagery at $1.5 \mathrm{~m}$ spatial resolution in 25 spectral channels of $10 \mathrm{~nm}$ width (O. Weatherbee pers. comm.). To avoid sun glint, overflights were conducted in the early morning and late afternoon when solar illumination angle was $<30^{\circ}$. Concurrent with the collection of upwelling spectral radiance, a Fiber Optic Downwelling Irradiance System (FODIS) incorporated in the AISA sensor package measured downwelling irradiance in the same spectral channels. Subsequent to the overflights, the apparent at-platform remote sensing reflectance $\left(R_{\mathrm{rs}}\right)$ was calculated for each spectral channel. A combined rudimentary atmospheric water-column radiance correction of the AISA spectral $R_{\mathrm{rs}}$ images, and also the IKONOS and ASTER imagery, was performed by use of the 'darkest pixel' method (Gordon 1978, Gordon \& Clark 1981), based on the sampling of adjacent deep-water pixels within the AISA coverage region. The AISA system was calibrated prior to the overflights with reference to NIST traceable integrating sphere $(\mathrm{O}$. Weatherbee pers. comm.).

Space Imaging's IKONOS satellite (Table 1) acquired a multispectral, $4 \mathrm{~m}$ spatial resolution image of the study area from an orbital altitude of $681 \mathrm{~km}$ on March 18, 2001, 70 d after the AISA overflight. Space Imaging provided radiometrically calibrated images in 3 visible region (400 to $700 \mathrm{~nm}$ ) spectral channels that vary from 60 to $80 \mathrm{~nm}$ in spectral band width (Space Imaging 2004). The IKONOS image was acquired in the morning, when the solar elevation angle was low enough to preclude significant sun glint. The Advanced Spaceborne Thermal Emission and Reflection Radiometer (ASTER) imaged the study area on January 31, 2001, $24 \mathrm{~d}$ after the AISA survey. The ASTER was placed on the NASA EOS Terra satellite by a United States-Japan cooperative project, and provides images at $15 \mathrm{~m}$ spatial resolution in 2 visible region spectral channels from an altitude of $705 \mathrm{~km}$ (Table 1; Abrams 2000). ASTER imaging occurred during morning low sun angle conditions to avoid sun glint.

The topography of the study area was surveyed during a 2 wk time period in early August 2002 by 

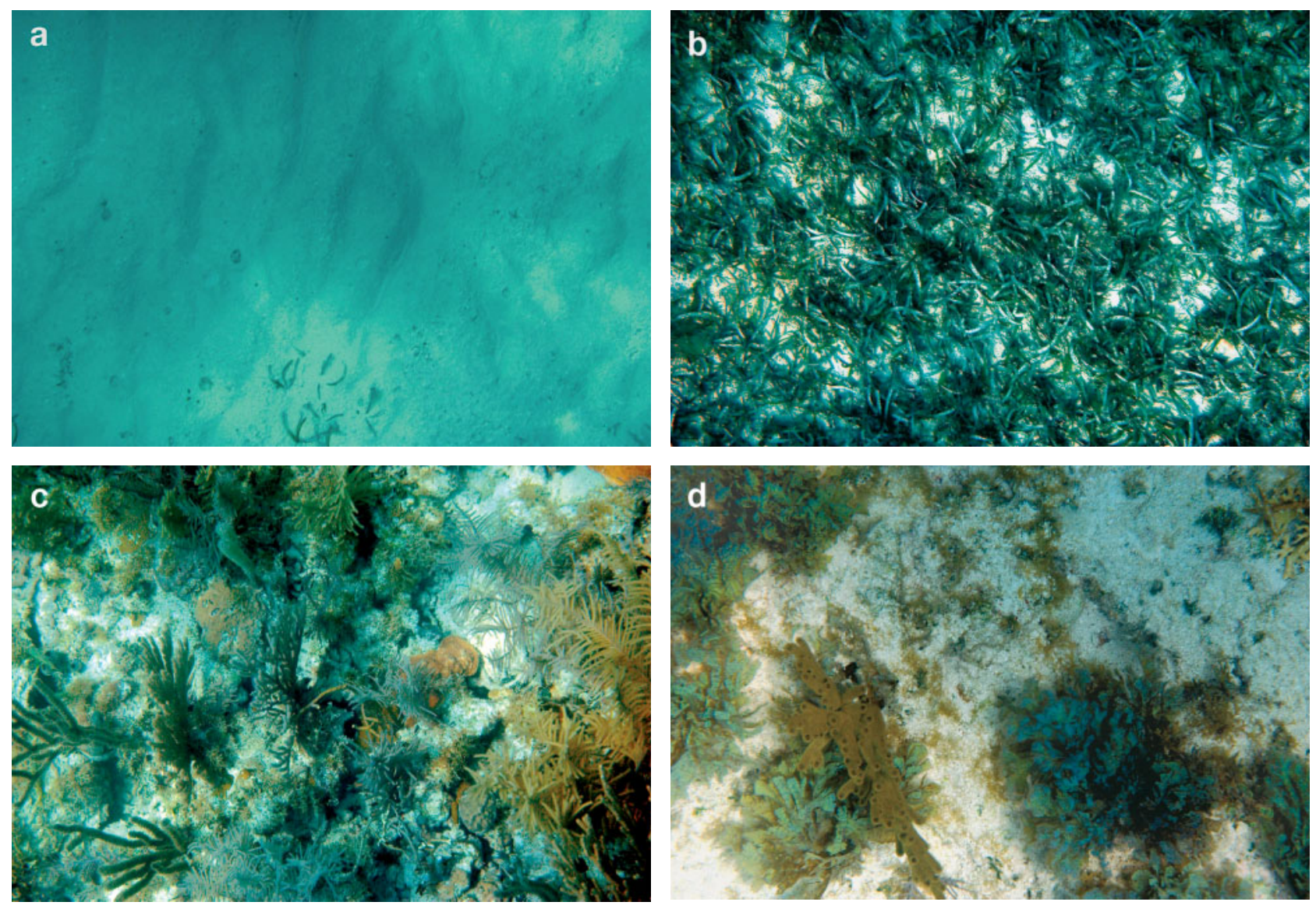

Fig. 2. Underwater photographs of the mapped biotopes, depicting (a) sand, (b) seagrass, (c) dense live substrate, and (d) sparse live substrate

Experimental Advanced Airborne Research Lidar (EAARL) overflights staged from Marathon, Florida (Brock et al. 2004). The EAARL is a temporal waveform-resolving, airborne light detection and ranging (lidar) instrument that is designed to measure the finescale topography of shallow reef substrates at a vertical resolution of about $15 \mathrm{~cm}$ at surface spot densities of at least one $20 \mathrm{~cm}$ diameter spot $\mathrm{m}^{-2}$ (Table 1) (Wright \& Brock 2002). The EAARL system includes a downlooking digital camera that continuously acquires digital aerial photographs at a $1.0 \mathrm{~s}$ time step and is co-registered to the EAARL optical system (Wright \& Brock 2002).

Creation of vertically resolved biotope maps. Following standard practice in the lidar surveying of dry land surfaces (Krabill \& Martin 1987, Fowler 2001), the EAARL system determines the geographic position of laser topographic soundings horizontally and vertically in relation to the constellation of Geographic Positioning System (GPS) satellites, requiring no Earth reference surface (Curry \& Schuckman 1993, Schwarz et al. 1993). The instantaneous aircraft location, lidar range measurements, and scan angle were combined to determine the Earth location of each benthic laser reflection to a horizontal precision of approximately $1 \mathrm{~m}$, and an absolute vertical precision of about $20 \mathrm{~cm}$ (Wright \& Brock 2002). The resulting substrate elevations were converted to the North American Datum of 1983 (NAD83) horizontal datum and the North American Vertical Datum of 1988 (NAVD88) mean sea-level vertical datum by the use of a geoid model (Krabill et al. 2000). The resulting point elevations were then gridded into $1.5 \mathrm{~m}$ wide cells to create a submarine digital elevation model that forms the morphologic component of the 3D biotope maps created from the AISA, IKONOS, and ASTER images. In the remainder of this report, all elevations are referenced to the North American Vertical Datum of 1988 (NAVD88), a mean sea-level vertical datum.

Ground geopositioning for the AISA pixels was provided to less than $5 \mathrm{~m}$ error in the Universal Transverse Mercator (UTM) projection system by an onboard OMNI STAR GPS receiver integrated with a C-Migits II inertial navigation system. The initial geometric correction of the IKONOS and ASTER images was based on the satellite ephemeris (Abrams 2000, Space Imag- 
ing 2004). The georectification of these satellite images was enhanced by image-warping to match the very well navigated aircraft lidar digital elevation model and hyperspectral imagery.

The AISA, IKONOS, and ASTER images underwent supervised classification based on the maximumlikelihood decision rule (Mumby et al. 1997a, 1998), using training sites identified from over 200 field survey points collected in March 2001 and 2002. Given that our investigation evaluated reef zone carbon fluxes, the classification discriminated very distinct substrate types that are well correlated with water depth and that could be unambiguously recognized in the field during the benthic chamber deployments. The benthic cover types that the supervised classification discriminated were identical for each image type, and were limited to sand, seagrass, and 2 coral reef classes, dense live substrate, and sparse live substrate (Fig. 2).

The sand class is consistently bare uncolonized carbonate sandy sediment (Fig. 2a), and the seagrass class is uniformly dense Thalassia testudinum seagrass meadow (Fig. 2b). The mean composition of the dense live substrate class (Fig. 2c) was determined by detailed benthic surveys of 12 patch reefs in the study region (I. B. Kuffner et al. unpubl.). In areal percentages, the dense live substrate class is mainly composed of bare lithified substrate $(21 \%)$, Dictyota spp. (15\%) and Halimeda tuna (12\%) algae, cyanobacteria (8\%), scleractinian coral (5\%), Millepora alcicornis hydrocoral (2\%), encrusting gorgonians and gorgonian holdfasts $(10 \%)$, and Porifera spp. (3\%). Gorgonian cover includes the encrusting species Erythropodium caribaeorum and Briareum asbestinum, as well as the holdfasts of branching species. Gorgonian holdfast areal coverage is a poor measure of the extreme abundance of branching gorgonians, as these octocorals occur at a mean spatial density of 32 specimens $\mathrm{m}^{-2}$. The encrusting zoanthid Palythoa carribaeorum (3\%) is also found in this biotope. The patch reef community is classified as sparse live substrate (Fig. 2d) rather than dense live substrate at locations where bare lithified substrate cover exceeds $50 \%$.

All of the remote sensing data used were collected in 2001 and 2002, within the 2000 to 2002 time period that covers the acquisition of the benthic incubation chamber measurements. No major storm impacted the study site during the 2000 to 2002 time period; therefore, we assume that the spatial pattern of benthic habitats did not vary significantly. Accordingly, the acquisition of mapping sensor observations in winter is not incompatible with the measurement of benthic metabolism in the spring and summer.
Digital camera images acquired in the study area in August 2002 were used to visually identify the actual benthic class at over 535 discrete random points (Fig. 3). This set of geolocated known substrate type values was used to evaluate the biotope maps created from the AISA, IKONOS, and ASTER images. A confusion matrix was developed to quantify the percentages of both correctly and incorrectly classified map cells.

In situ metabolic measurements. The Submersible Habitat for Assessing Reef Quality (SHARQ) was deployed over various biotopes in the study area during June 27 to July 1, 2000, May 30 to June 2, 2001, and July 12 to 13,2002 to measure diurnal springsummer rates of calcification, photosynthesis, and respiration (Yates \& Halley 2003). The SHARQ is a large (4.9 $\mathrm{m}$ long $\times 2.4 \mathrm{~m}$ wide $\times 1.2 \mathrm{~m}$ high) portable incubation system that acquires in situ measurements of community-scale metabolic rates by isolating the water mass overlying the substrate, thereby allowing the monitoring of changes in water chemistry over time (Fig. 4). A detailed description of the SHARQ design and operation is provided by Yates \& Halley (2003).

The SHARQ differs from most benthic chambers by replicating to a large degree the natural circulation in this part of the NFRT. This is accomplished in 2 ways. First, the SHARQ contains a circulation system that produces turbulent flow in the chamber at current

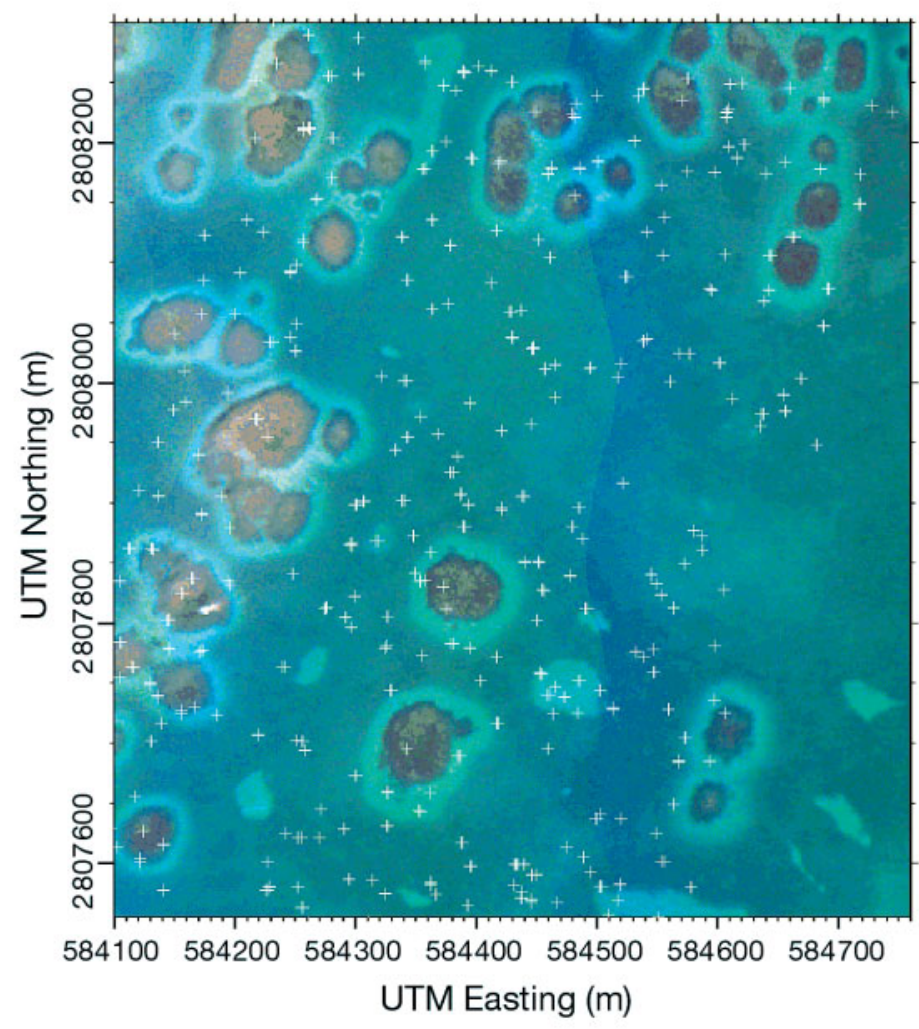

Fig. 3. AISA false-color composite image of the study area, with in situ benthic observation points marked as white crosses 


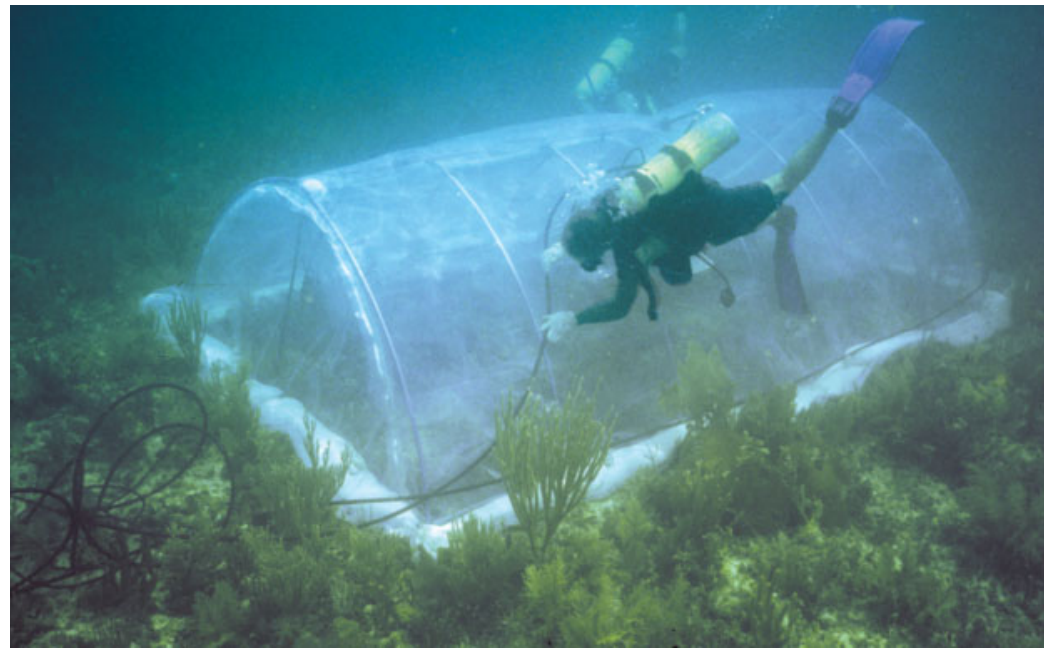

Fig. 4. The Submersible Habitat for Analyzing Reef Quality (SHARQ), a large benthic incubation chamber that allows the $24 \mathrm{~h}$ monitoring of water chemistry variations driven by substrate carbon and carbonate metabolic processes defined in the supervised classification of the AISA, IKONOS, and ASTER images. This procedure established the rates of daily spring-summer gross photosynthesis, respiration, and net calcification for the mapped substrates that were subsequently used in estimating spatially integrated carbon and carbonate fluxes.

Technique for spatial extrapolation of metabolism. A raster model implemented in the Interactive Data Language (IDL) at $1.5 \mathrm{~m}$ grid cell resolution was used to extrapolate the SHARQ metabolic measurements across the AISA, IKONOS, and ASTER-based benthic class maps. This operation resulted in a set of maps for each mapping sensor that depicted the estimated spatial patterns of spring-summer daytime calcification $\left(G ; \mathrm{g} \mathrm{CaCO}_{3} \mathrm{~m}^{-2} \mathrm{~d}^{-1}\right)$, speeds similar to those measured on this platform (Lee 1986, Haus et al. 2000). Second, the flexible structure of the SHARQ propagates oscillatory flow through the chamber as waves pass over the study area.

Water depth at the SHARQ study area sites ranged from about 3 to $10 \mathrm{~m}$, and temperature and salinity ranged from 27.3 to $30.2^{\circ} \mathrm{C}$ and 33.6 to $35.4 \%$, respectively. During $24 \mathrm{~h}$ incubation periods at each site, the SHARQ was used to measure community metabolism over the mapped substrate types. The benthic cover at each SHARQ site was measured by use of photoquads. The circumferences of all coral colonies within the incubation chamber were also measured (Yates \& Halley 2003).

Following the method of Kinsey (1978), we measured total alkalinity $(T A)$, dissolved oxygen $\left(\mathrm{O}_{2}\right), \mathrm{pH}$, salinity, and water temperature and calculated community metabolism. Net calcification was determined for each of six $4 \mathrm{~h}$ periods within each $24 \mathrm{~h}$ incubation period using the alkalinity anomaly technique of Smith \& Key (1975). Net photosynthesis and respiration were calculated from dissolved $\mathrm{O}_{2}$ at 15 min intervals. Net metabolic rates per unit area of substrate were obtained by multiplying the $\mathrm{O}_{2}$ concentration change by the volume to basal surface area ratio of the chamber. Diurnal curves for net photosynthesis and respiration were developed based on the determinations for $15 \mathrm{~min}$ intervals. Daily gross production was calculated by integrating the daytime photosynthesis curves established for instantaneous gross production. A $24 \mathrm{~h}$ respiration estimate was based on the mean rates of respiration measured during each incubation period (Yates \& Halley 2003). Mean metabolic rates were calculated for representative sites selected for each benthic class daily gross photosynthesis $\left(P, \mathrm{~g} \mathrm{C} \mathrm{m}^{-2} \mathrm{~d}^{-1}\right)$, and $24 \mathrm{~h}$ respiration $\left(R_{;} \mathrm{g} \mathrm{C} \mathrm{m}^{-2} \mathrm{~d}^{-1}\right)$. A map showing excess production $\left(E ; \mathrm{g} \mathrm{C} \mathrm{m}^{-2} \mathrm{~d}^{-1}\right.$ ) was created for each sensor type by differencing the corresponding estimated spatial distributions of $P$ and $R$. For each sensor, the $E$ and $G$ distributions created using the corresponding benthic cover map were spatially integrated by benthic class. Finally, the flux distributions shown on the AISA, IKONOS, and ASTER-based reefscape metabolism maps were integrated across all benthic cover types and over space to estimate the total and class-specific carbon and carbonate benthic flux estimates for the study area, and to allow sensor-to-sensor comparisons.

The knowledge of class-to-class discrimination error obtained from the map accuracy analysis was used to correct the total class areas obtained for the AISAbased biotope map. The corrected AISA-mapped areas were then used to most accurately estimate the total carbon and carbonate benthic fluxes for each biotope and for the entire study area. Holistic study area rates of $G, P, R$, and $E$, and $P / R$ ratios were calculated as weighted averages by combining the SHARQ measurements with the biotope areal coverage estimates obtained from the AISA, IKONOS, ASTER and AISAcorrected mapping analyses.

\section{RESULTS}

\section{Accuracy of vertically resolved biotope maps}

The $1.5 \mathrm{~m}$ resolution EAARL submarine topography map created for the study area ranges in elevation from -2.3 to $-12.4 \mathrm{~m}$ (Fig. 5a). Clusters of patch reefs 

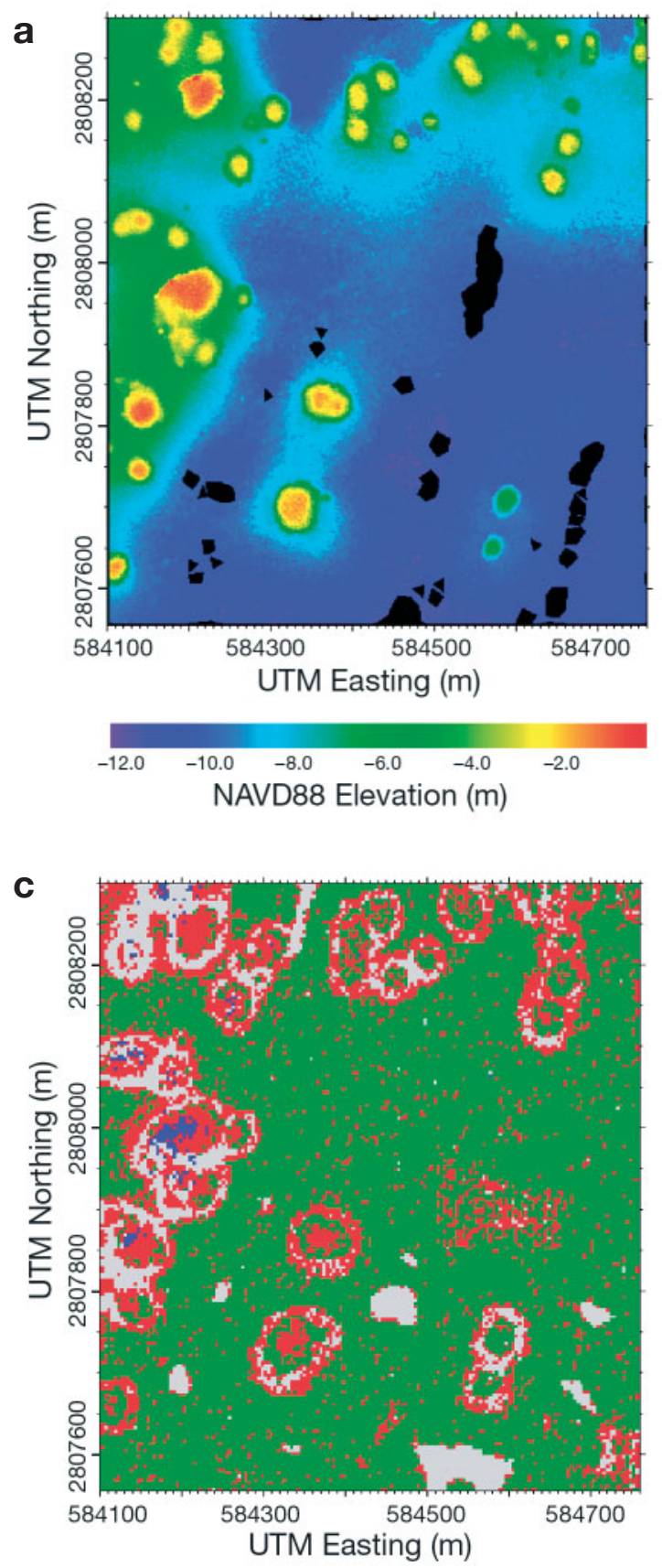
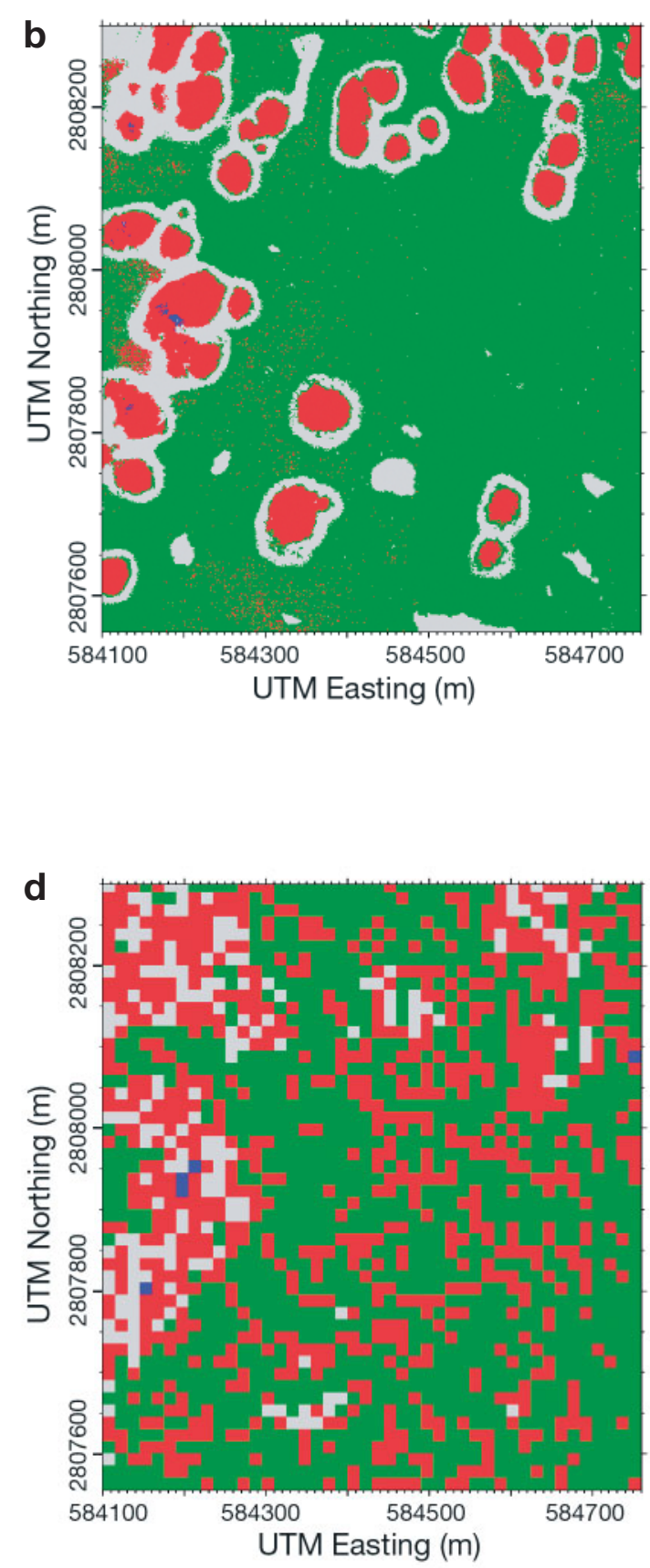

Fig. 5. (a) Submarine topographic map based on NASA EAARL lidar surveys. Areas shown in black represent regions where laser soundings of bottom elevation were not obtained. Benthic habitat classification maps based on (b) AISA airborne hyperspectral imagery, and (c) IKONOS, and (d) ASTER multispectral satellite imagery

that overlie slight topographic highs at about $-6 \mathrm{~m}$ are apparent along the north and west margins of the study area. In addition, several scattered patch reefs reside in the center and southeast portions of the study area where the platform is slightly deeper at about $-10 \mathrm{~m}$. The EAARL lidar soundings capture detailed substrate morphology at a vertical precision of within $20 \mathrm{~cm}$ (Brock et al. 2004). This capability to capture fine scale topographic detail is evident across the crest of Alina Reef, the large patch reef situated directly west of the study area centerpoint (Fig. 5a).

The AISA-based biotope map (Fig. 5b) clearly depicts the distribution of live substrate on patch reefs ringed by sand halos, and the seagrass and sand distribution on the adjacent platform, closely matching the EAARL submarine topographic map (Fig. 5a). Use 
Table 2. Accuracies for the AISA, IKONOS, and ASTER image classification maps. Correct classification percentages shown in bold

\begin{tabular}{|c|c|c|c|}
\hline \multirow[t]{2}{*}{ Actual class } & \multirow[b]{2}{*}{$\begin{array}{c}\text { Sand } \\
(\%)\end{array}$} & \multicolumn{2}{|c|}{ Mapped as class } \\
\hline & & $\begin{array}{c}\text { Seagrass } \\
(\%)\end{array}$ & $\begin{array}{l}\text { Combined live } \\
\text { substrate }(\%)\end{array}$ \\
\hline \multicolumn{4}{|l|}{ AISA-based map } \\
\hline Sand & 85.1 & 12.8 & 2.1 \\
\hline Seagrass & 9.6 & 86.8 & 3.6 \\
\hline Combined live substrate & 6.6 & 11.5 & 82.0 \\
\hline \multicolumn{4}{|l|}{ IKONOS-based map } \\
\hline Sand & 8.5 & 78.7 & 12.8 \\
\hline Seagrass & 6.3 & 77.3 & 16.4 \\
\hline Combined live substrate & 16.4 & 57.4 & 26.2 \\
\hline \multicolumn{4}{|l|}{ ASTER-based mapping } \\
\hline Sand & 12.8 & 78.7 & 8.5 \\
\hline Seagrass & 3.6 & 71.3 & 25.1 \\
\hline Combined live substrate & 9.8 & 68.8 & 21.3 \\
\hline
\end{tabular}

\section{Variation in metabolic rates}

The patch reef communities investigated with the SHARQ in the study area are dominated by octocorals, a variety of scleractina (Montastrea annularis, Porites astreoides, Acropora cervicornis, Siderastrea siderea), several species of Halimeda, and coralline algae (Yates \& Halley 2003). The seagrass beds on the adjacent platform are uniformly dense and are composed of Thalassia testudinum. The diurnal variation in gross photosynthesis and respiration for all substrate types is similar to the classical patterns reported by Marsh \& Smith (1978) and Kinsey (1978). Mean $P$ was highest on patch reefs at $6.43 \mathrm{~g} \mathrm{C} \mathrm{m}^{-2} \mathrm{~d}^{-1}$, the lowest $P$ values were associated with sand bottoms $\left(1.76 \mathrm{~g} \mathrm{C} \mathrm{m}^{-2} \mathrm{~d}^{-1}\right)$, and the daily mean seagrass $P$ was $2.88 \mathrm{~g} \mathrm{C} \mathrm{m}^{-2} \mathrm{~d}^{-1}$

of the AISA imagery resulted in classification accuracies at or higher than $82 \%$ for all biotopes, a result that was markedly superior to the accuracies achieved with IKONOS or ASTER (Table 2). The IKONOSbased map (Fig. 5c) more clearly captures the general benthic spatial pattern than does the ASTER-based map (Fig. 5d), but the biotope maps based on the 2 types of satellite imagery are both inferior to the AISA-based map in accuracy (Table 2). Both IKONOS and ASTER performed best in discriminating seagrass, with respective accuracies of 77 and $71 \%$, but at sand classification accuracies of $8 \%$ (IKONOS) and $13 \%$ (ASTER), these sensors failed to reliably capture the sand halos that rim patch reefs (Table 2). At accuracies of 26 and $21 \%$, respectively, both IKONOS and ASTER poorly differentiated the live substrate on patch reefs (Table 2).

The hyperspectral, high spatial resolution aircraft survey enabled the best discrimination of narrow sand halos, resulting in the greatest total area mapped as sand $\left(75195 \mathrm{~m}^{2}\right)$, roughly twice the total sand area on the ASTER-based map (39735 $\mathrm{m}^{2}$ ) (Fig. 6). The superiority of the AISA in discriminating seagrass resulted in a greater total area of seagrass $\left(353623 \mathrm{~m}^{2}\right)$ relative to the coverage of this class on the ASTER map $\left(275265 \mathrm{~m}^{2}\right)$. Mapping based on IKONOS, and especially ASTER, grossly overestimated the total area of live substrate cover, resulting in total areas roughly 2 (IKONOS) or 3 (ASTER) times the live substrate cover on the AISA-based map $\left(62221 \mathrm{~m}^{2}\right)$. In order to derive the most accurate possible estimates of total biotope area, the AISA results were adjusted by using the results of the map accuracy analysis. This correction caused a $36 \%$ increase in the AISA total class area of sand, an $8 \%$ decrease in total seagrass area, and a $5 \%$ increase in total live substrate area (Fig. 6).
(Table 3). The lowest rates of mean $R$ were associated with sand $\left(1.96 \mathrm{~g} \mathrm{C} \mathrm{m}^{-2} \mathrm{~d}^{-1}\right)$, seagrass $R$ was intermediate at $3.32 \mathrm{~g} \mathrm{C} \mathrm{m}^{-2} \mathrm{~d}^{-1}$, and the highest rate was associated with patch reef bottoms $\left(8.09 \mathrm{~g} \mathrm{C} \mathrm{m}^{-2} \mathrm{~d}^{-1}\right)$. $P / R$ ratios were less than 1.0 and similar for all substrate types at $0.90,0.87,0.79$, and 0.80 , for sand, seagrass, dense live substrate, and sparse live substrate, respectively.

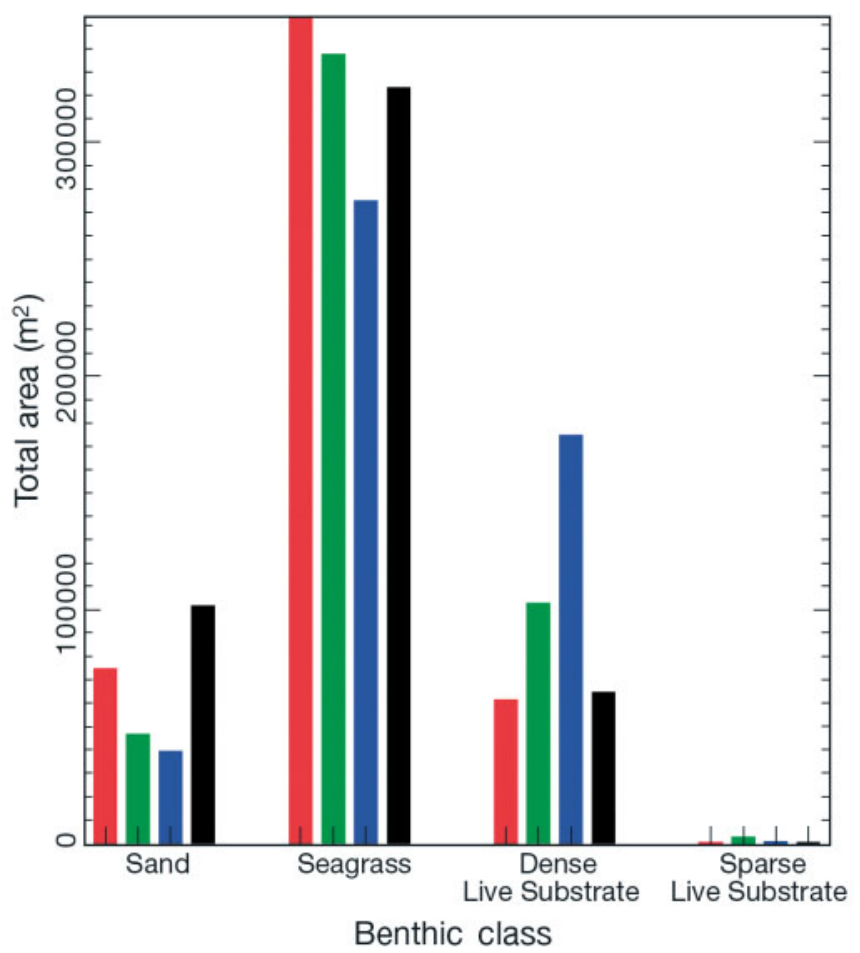

Fig. 6. Total mapped areas for each classified benthic class based on the AISA (red), IKONOS (green), ASTER (blue) and AISA-corrected (black) analyses 
Table 3. Daily summertime community metabolic rates for mapped substrate classes based on SHARQ measurements. Fluxes listed are net calcification $(G)$, gross photosynthesis $(P), 24 \mathrm{~h}$ respiration $(R)$, and excess production $(E)$. If more than one measurement was acquired for a substrate class, the number of observations, mean, minimum, maximum rates, and the rate SDs are provided

\begin{tabular}{|c|c|c|c|c|c|c|c|}
\hline Class & $\begin{array}{l}\text { Nun } \\
\text { obser }\end{array}$ & $\begin{array}{l}\text { aber of } \\
\text { vations }\end{array}$ & $\begin{array}{c}G \\
\left(\mathrm{~g} \mathrm{CaCO}_{3} \mathrm{~m}^{-2} \mathrm{~d}^{-1}\right)\end{array}$ & $\begin{array}{c}P \\
\left(\mathrm{~g} \mathrm{C} \mathrm{m}^{-2} \mathrm{~d}^{-1}\right)\end{array}$ & $\begin{array}{c}R \\
\left(\mathrm{~g} \mathrm{C} \mathrm{m}^{-2} \mathrm{~d}^{-1}\right)\end{array}$ & $\begin{array}{c}E \\
\left(\mathrm{~g} \mathrm{C} \mathrm{m}^{-2} \mathrm{~d}^{-1}\right)\end{array}$ & $P / R$ \\
\hline Sand & 1 & & 0.11 & 1.76 & 1.96 & -0.20 & 0.90 \\
\hline Seagrass & & $\begin{array}{l}\text { Mean } \\
\text { Min. } \\
\text { Max. }\end{array}$ & $\begin{array}{l}-0.19 \\
-0.40 \\
-0.03\end{array}$ & $\begin{array}{l}2.88 \\
2.29 \\
3.60\end{array}$ & $\begin{array}{l}3.32 \\
2.86 \\
4.02\end{array}$ & -0.44 & 0.87 \\
\hline Dense live substrate & & $\begin{array}{l}\text { Mean } \\
\text { Min. } \\
\text { Max. }\end{array}$ & $\begin{array}{l}1.29 \\
0.82 \\
1.76\end{array}$ & $\begin{array}{l}6.43 \\
6.41 \\
6.45\end{array}$ & $\begin{array}{l}8.09 \\
8.08 \\
8.10\end{array}$ & -1.66 & 0.79 \\
\hline Sparse live substrate & 1 & & -0.04 & 4.23 & 531 & -1.08 & 0.80 \\
\hline
\end{tabular}

During daylight hours, calcification exceeded dissolution at all SHARQ sites, in contrast to the night, when dissolution processes dominated, except at one of the patch reef sites (Yates \& Halley 2003). The highest mean rate of $G, 1.29 \mathrm{~g} \mathrm{CaCO}_{3} \mathrm{~m}^{-2} \mathrm{~d}^{-1}$ (Table 3), was measured on the dense communities found atop patch reefs, typically sites of the most extreme calcification: dissolution ratios (Yates \& Halley 2003). G was lower but still positive over sand bottoms $\left(0.11 \mathrm{~g} \mathrm{CaCO}_{3} \mathrm{~m}^{-2}\right.$ $\mathrm{d}^{-1}$, near zero in coral reef areas of sparse live substrate $\left(-0.04 \mathrm{~g} \mathrm{CaCO}_{3} \mathrm{~m}^{-2} \mathrm{~d}^{-1}\right)$, and negative in seagrass beds, where the assigned mean class value was found to be $-0.19 \mathrm{~g} \mathrm{CaCO}_{3} \mathrm{~m}^{-2} \mathrm{~d}^{-1}$. The number of SHARQ incubations per class was $1,4,2$, and 1 for sand, seagrass, dense live substrate, and sparse live substrate, respectively (Table 3), insufficient to draw any conclusion with respect to intra-biotope metabolic variability.

\section{Space-integrated benthic carbon and carbonate metabolism}

The estimated spatial distributions of $P, R, E$, and $G$ were constructed by assigning SHARQ-determined metabolic rates to the benthic-classes mapped by AISA, IKONOS, and ASTER. Although the analysis was performed for all mapping sensor types, metabolic rate maps are only presented for the AISA-based benthic class map, determined to be the most accurate representation of the actual spatial biotope distribution (Fig. 7). Accordingly, the spatial patterns shown on the $G, P, R$, and $E$ metabolic rate maps (Fig. 7) match the corresponding AISA-based benthic class map.

Integration of the metabolic rate maps constructed for each mapping sensor resulted in estimates of the biotope-specific total study area $E\left(\mathrm{~kg} \mathrm{C} \mathrm{d}^{-1}\right)$ and $G$ $\left(\mathrm{kg} \mathrm{CaCO} \mathrm{C}^{-1}\right)$ fluxes. The analysis based on the cor- rected AISA total biotope areas, taken to be the most accurate, demonstrated that all 4 mapped biotopes are heterotrophic, and that live substrate and seagrass result in significant net negative $E$ values of $-108.8 \mathrm{~kg}$ $\mathrm{C} \mathrm{d}^{-1}$ and $-145.7 \mathrm{~kg} \mathrm{C} \mathrm{d}^{-1}$, respectively. The corrected AISA analysis also reveals that organic carbon and carbonate fluxes due to sand and sparse live substrate are minor within the study area. Net positive calcification on patch reefs in the study area is estimated to be $84.2 \mathrm{~kg} \mathrm{CaCO}_{3} \mathrm{~d}^{-1}$, while total net dissolution of $61.5 \mathrm{~kg} \mathrm{CaCO}_{3} \mathrm{~d}^{-1}$ is calculated to occur in seagrass meadows. The diminished accuracies of the benthic class maps based on IKONOS and ASTER do not substantially alter the total organic carbon and carbonate flux estimates associated with sand, sparse live substrate, or seagrass. However, relative to the corrected AISA analysis, the IKONOS analysis, and especially the ASTER analysis, significantly overestimated total calcification and organic carbon import by live substrate.

Holistic estimates of total $E$ and $G$ for the study area were obtained by summing the biotope-specific flux estimates. The corrected AISA analysis reveals that the study area as a whole is heterotrophic, receiving external organic carbon at an estimated rate of $274.8 \mathrm{~kg} \mathrm{~d}^{-1}$. Further, the study area overall fixes about $34.4 \mathrm{~kg}$ $\mathrm{CaCO}_{3} \mathrm{~d}^{-1}$, due to calcification on shallow patch reefs and sandy bottoms that is largely offset by net dissolution within the deeper platform seagrass meadows. Both the IKONOS and ASTER analyses overestimated the net heterotrophic performance and overall calcification of the study area. However, the respective errors relative to the corrected AISA results for negative $E$ and positive $G$ are much higher for the ASTER analysis $(48,431 \%)$ than for the IKONOS analysis $(19,125 \%)$.

To enable comparison with prior investigations based on flow respirometry, holistic daily summertime 


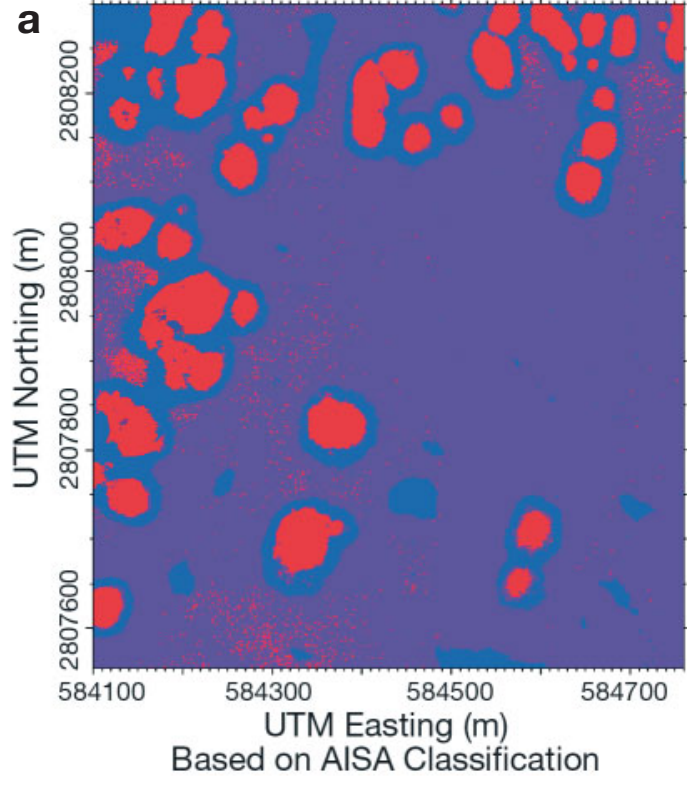

$\begin{array}{llllllllllllll}-0.1 & 0 & 0.1 & 0.2 & 0.3 & 0.4 & 0.5 & 0.6 & 0.7 & 0.8 & 0.9 & 1.0 & 1.1 & 1.2\end{array}$ $\left(\mathrm{g} \mathrm{CaCO}_{3} \mathrm{~m}^{-2}\right)$

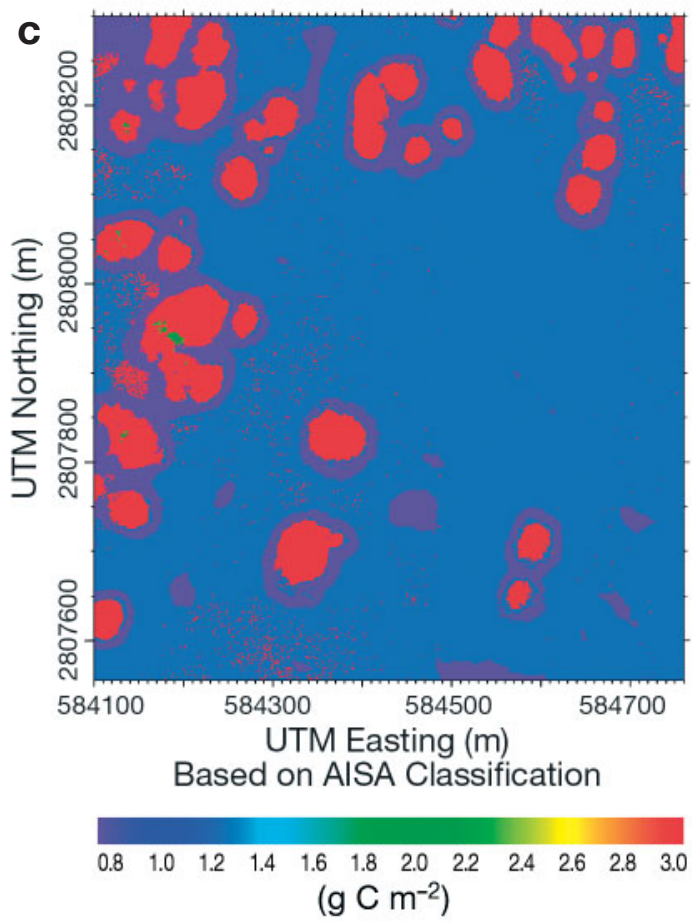

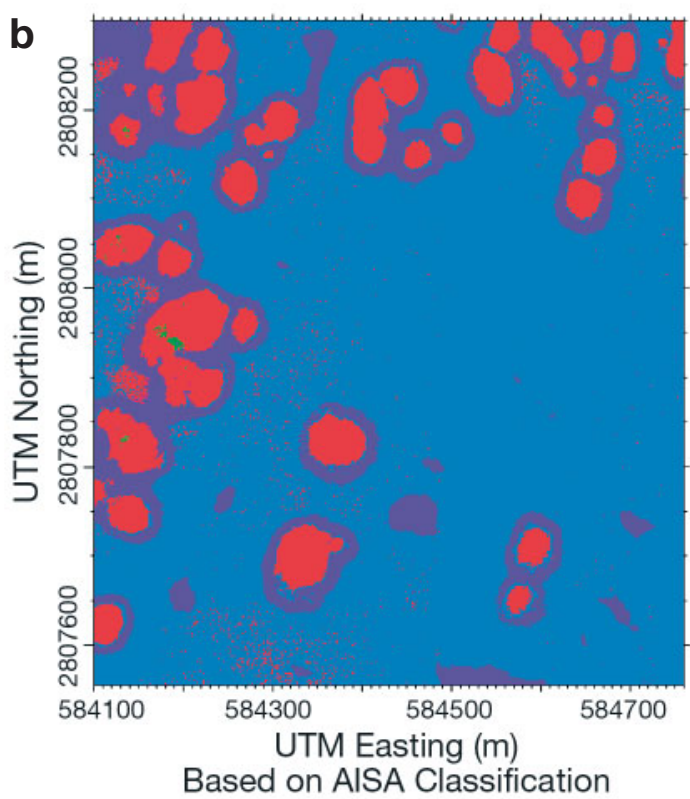
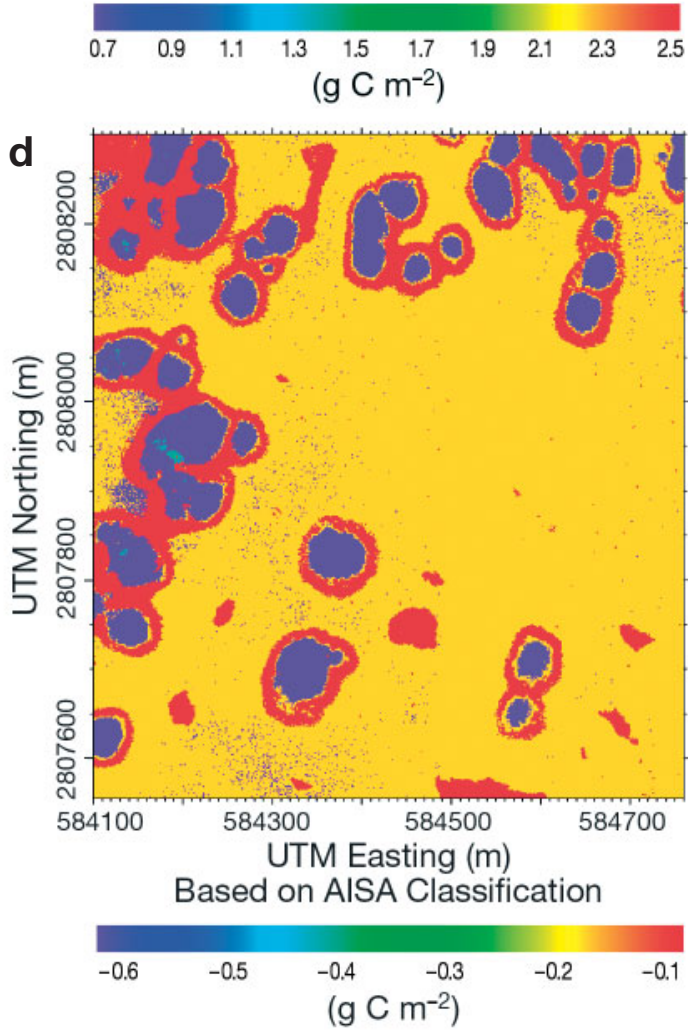

Fig. 7. Total estimated daily summertime (a) net calcification $\left(\mathrm{g} \mathrm{CaCO}_{3} \mathrm{~m}^{-2} \mathrm{~d}^{-1}\right)$, (b) gross primary production $\left(\mathrm{g} C \mathrm{~m}^{-2} \mathrm{~d}^{-1}\right)$, (c) respiration $\left(\mathrm{g} \mathrm{C} \mathrm{m}^{-2} \mathrm{~d}^{-1}\right)$, and (d) excess production $\left(\mathrm{g} \mathrm{C} \mathrm{m}^{-2} \mathrm{~d}^{-1}\right)$

community metabolic rates were calculated by dividing the total carbon and carbonate fluxes by the total area of the study region (Table 4). Based on the most accurate corrected AISA analysis, the areanormalized holistic $E$ and $G$ rates for the study region are estimated to be $-0.56 \mathrm{~g} \mathrm{C} \mathrm{m}^{-2} \mathrm{~d}^{-1}$ and $0.07 \mathrm{~g} \mathrm{CaCO}_{3}$ $\mathrm{m}^{-2} \mathrm{~d}^{-1}$, respectively. Moreover, the corrected AISA analysis resulted in a holistic study area daily $P$ of $3.11 \mathrm{~g} \mathrm{C} \mathrm{m}^{-2} \mathrm{~d}^{-1}$, an $R$ rate of $3.67 \mathrm{~g} \mathrm{C} \mathrm{m}^{-2} \mathrm{~d}^{-1}$, and a $P / R$ of 0.85 . 
Table 4. Holistic study area daily summertime community metabolic rates and $P / R$ ratios based on SHARQ measurements scaled by remote sensing. Fluxes listed are net calcification $(G)$, gross photosynthesis $(P), 24 \mathrm{~h}$ respiration $(R)$, and excess production $(E)$

\begin{tabular}{|lcccc|}
\hline Imagery type & $G\left(\mathrm{~g} \mathrm{CaCO}_{3} \mathrm{~m}^{-2} \mathrm{~d}^{-1}\right)$ & $P\left(\mathrm{~g} \mathrm{C} \mathrm{m}^{-2} \mathrm{~d}^{-1}\right)$ & $R\left(\mathrm{~g} \mathrm{C} \mathrm{m}^{-2} \mathrm{~d}^{-1}\right)$ & $E\left(\mathrm{~g} \mathrm{C} \mathrm{m}^{-2} \mathrm{~d}^{-1}\right)$ \\
\hline AISA & 0.04 & 3.15 & 3.71 & -0.565 \\
IKONOS & 0.15 & 3.52 & 4.20 & -0.684 \\
ASTER & 0.36 & 4.05 & 4.91 & -0.86 \\
AISA corrected & 0.07 & 3.11 & 3.67 & -0.56 \\
\hline
\end{tabular}

\section{DISCUSSION}

Historically, community-scale measurements of reef metabolic processes have been performed using a flow respirometry approach based on the lagrangian monitoring of the chemistry of water mass passing over a reef zone (Kinsey 1985). Flow respirometry requires that water circulation at the study site be well characterized using current meters or other water-mass tracking techniques, assumes the conservation of water mass along transects, and requires unidirectional currents (Yates \& Halley 2003). Flow respirometry is also limited by the resolution of geochemical measurements, and is difficult or impossible to employ at night. Further, the irregular topography of coral reefs complicates the use of flow respirometry, resulting in the potential for large errors. Therefore, although traditional flow respirometry is of great value in well constrained settings within reef zones, we regard this method to be insufficient for the estimation of the metabolism of reef zones with complex structure.

Our study has demonstrated that an alternative approach, the integration of biotope mapping by remote sensing with local metabolic functions determined through in situ process measurements, allows the estimation of reef system excess organic carbon production and calcification at intra-reef zone biotope scale. Although current remote sensing methods cannot provide local community metabolic rates (Joyce \& Phinn 2003), our study has demonstrated that large portable incubation systems (Yates \& Halley 2003) provide this capability if deployed at sites defined by remotely sensed biotope distributions. Also, benthic chamber experiments under varying light and nutrient conditions have the potential to enable the definition of biotope-specific metabolic algorithms for photosynthesis, respiration, and calcification. Further, deployment is not limited due to current patterns, and the large footprint enables measurement of community-scale fluxes (Yates \& Halley 2003).

\section{Mapping sensor accuracies and metabolic scaling}

Recent studies have led to a consensus that high spatial/high spectral resolution airborne sensors are superior to satellite sensors in capturing the biotic diversity of coastal systems (Andrefouet et al. 2003, Call et al. 2003, Held et al. 2003, Malthus \& Mumby 2003, Thompson et al. 2003). Advantages of airborne scanning include the possibility of more spectral bands than are employed on satellite sensors, affording the ability to measure complete reflectance spectra, the capability for multiple sensor integration, and the ability to acquire very high spatial resolution scans in digital format (Mumby et al. 1997a).

The AISA class mapping accuracies above $80 \%$ (Table 2) found by this study are consistent with prior findings on the capabilities of aerial imaging (Catt \& Hopley 1988, Thamrongnawasawat \& Hopley 1994, Green et al. 1996), and especially airborne hyperspectral scanning (Mumby et al. 1997a,b, 2001, Hochberg \& Atkinson 2000), in the mapping of coral reef habitats. Our study has clearly demonstrated that airborne hyperspectral scanning at spatial resolutions approaching $1 \mathrm{~m}$ is the preferred mapping method for the scaling of metabolic processes in coral reef ecosystems.

The failure of ASTER to classify the shallow patch reef community reliably as dense or sparse live substrate, or to discriminate deeper platform seagrass from reef accurately, is consistent with prior evaluations of intermediate resolution satellite sensors for the mapping of coral reef habitats. Various prior studies have concluded that moderate resolution satellite imagery does not yield reliable quantitative estimates of coral cover or coral spatial distribution (Bainbridge \& Reichelt 1988, Ahmad \& Neil 1994, Green et al. 1996, Dustan et al. 2000). In the case of ASTER, these mapping limitations resulted in respective errors in $E$ and $G$ of 48 and $431 \%$, and accordingly, we cannot recommend ASTER or similar spatial resolution multispectral satellite sensors for the scaling of reef system carbon and carbonate fluxes. 
The $4 \mathrm{~m}$ spatial resolution of IKONOS is quite high for a multispectral satellite sensor, and this has led some researchers to anticipate significant capabilities for creating ecologically useful biotope classifications for littoral zones (Malthus \& Mumby 2003). These expectations are substantiated to some degree by the current study, given that the holistic $E$ and $G$ rates determined based on IKONOS mapping are markedly less in error $(19 \%, 125 \%)$ relative to the corrected AISA results than are the ASTER-based estimates $(48 \%, 431 \%)$. Mumby \& Edwards (2002) suggested the use of image texture to refine reef system biotope maps derived from IKONOS. We regard this as a possible means to upgrade map accuracy and thereby enable the use of IKONOS-based maps in the spatial scaling of benthic biogeochemical processes. Capolsini et al. (2003) found that MASTER and IKONOS performed best in high-complexity reef mapping, suggesting that enhanced spatial, spectral, and radiometric resolutions all contribute to improved fine-scale habitat mapping (Capolsini et al. 2003). We do anticipate some restrictions on the use of IKONOS in metabolic studies at the community scale because the high IKONOS spatial resolution relative to other satellite sensors is not matched by commensurate improvements in spectral or radiometric resolution (Dustan et al. 2000, Lubin et al. 2001, Andrefouet et al. 2003).

\section{Holistic metabolic function}

During the last century, the NFRT has been subjected to catastrophic hurricanes, cold water events, disease and bleaching outbreaks, and the cumulative impacts of overfishing (Burns 1985, Ault et al. 1998, Hoegh-Guldberg 1999, Jones \& Boyer 2001, Mueller et al. 2001, Porter et al. 2001). Gradual decline in water quality (Hudson et al. 1994, Cook et al. 2002), increases in seasonal temperature (Hudson 1981) and salinity fluctuations (Porter et al. 1999) have resulted in degradation of the environmental conditions needed for coral growth and survival.

Beyond south Florida, natural and anthropogenic stresses have resulted in the large scale degradation of coral reefs both globally (Dubinsky \& Stambler 1996) and throughout the Caribbean region (Tomascik \& Sander 1985, Hallock et al. 1993, Hughes 1994, Kramer 2003). Similar phase shifts have occurred over the last several decades in the Florida reef tract, where coral bleaching has become more frequent and more persistent (Causey et al. 2002a), disease prevalence has increased (Mueller et al. 2001, Porter et al. 2002), and stoney coral cover has declined dramatically (Causey et al. 2002b). Massive bleaching outbreaks driven by high sea surface temperatures and quiescent winds were first observed in the Lower Keys along the outer reef tract in 1983, and then expanded and moved shoreward during 1987, 1990, and 1997 to 1998 events (Hoegh-Guldberg 1999). Serial overfishing has dramatically altered reef fish populations throughout the Florida reef tract, leaving 23 of 35 market fish species now recognized as overfished (Ault et al. 2001). Between 1996 and 2000, 66\% of 160 monitoring stations in the Florida Keys National Marine Sanctuary (FKNMS) showed losses in stoney coral diversity, and stoney coral cover on reefs decreased by $36.6 \%$ to just $6.6 \%$ of total cover (Jaap et al. 2001). Monitoring in this time period also found increases in diseased coral and the number of disease types (Jaap et al. 2001).

The holistic study area calcification rate of $0.07 \mathrm{~g}$ $\mathrm{CaCO}_{3} \mathrm{~m}^{-2} \mathrm{~d}^{-1}$ estimated by our scaling analysis is negligible, especially if compared to modal values for reef zone metabolic performance in similar seaward backreef settings worldwide, reported to be $4 \pm 1 \mathrm{~g}$ $\mathrm{CaCO}_{3} \mathrm{~m}^{-2} \mathrm{~d}^{-1}$ in 'standard' reef flats (Kinsey 1985). At a mean value of $6.4 \mathrm{~g} \mathrm{CaCO}_{3} \mathrm{~m}^{-2} \mathrm{~d}^{-1}, G$ on patch reefs was low relative to the range of 11 to $32 \mathrm{~g} \mathrm{CaCO}_{3}$ $\mathrm{m}^{-2} \mathrm{~d}^{-1}$ reported by Kinsey (1985) for high activity areas of near total cover by hard substratum investigated in the Pacific and Caribbean basins. The depressed patch reef $G$ value in the study region is consistent with the well documented decline of the Florida reef tract and associated loss of stoney coral cover. A second reason for the quite low holistic study region $G$ value is the dissolution that occurs in seagrass meadows at a rate of $-0.19 \mathrm{~g} \mathrm{CaCO}_{3} \mathrm{~m}^{-2} \mathrm{~d}^{-1}$, over an area that exceeds patch reef cover by $396 \%$.

Although near the perimeter of the reef system, the backreef carbonate platform of the NFRT was determined to be net heterotrophic across all substrates, with a holistic excess production rate of $-0.56 \mathrm{~g} \mathrm{C} \mathrm{m}^{-2} \mathrm{~d}^{-1}$ and an overall $P / R$ ratio of 0.85 . Note that while our process measurements were made during summer high light conditions favorable to photosynthesis, all of the mapped biotopes, including the seagrass meadows, were observed to have $P / R$ ratios less than one. Backreef platforms immediately landward of the reef crest generally tend towards net autotrophy, with $P$ ranging from 2.6 to $40.0 \mathrm{~g} \mathrm{C} \mathrm{m}^{-2} \mathrm{~d}^{-1}$ and $P / R$ ratios of 0.7 to 3.2 (Hatcher 1990). In contrast, our site on a backreef platform just landward of the NFRT barrier-bank reef zone has a comparatively low holistic gross primary production rate of $3.1 \mathrm{~g} \mathrm{C} \mathrm{m}^{-2} \mathrm{~d}^{-1}$ that is exceeded by the overall respiration rate of $3.7 \mathrm{~g} \mathrm{C} \mathrm{m}^{-2} \mathrm{~d}^{-1}$.

Although the NFRT is downstream from major potential sources of inorganic nutrients in the Gulf of Mexico (Boyer \& Jones 2002) and south Florida (Lapointe \& Clark 1992, Lapointe et al. 1993, 2002), the net autotrophy that might be expected to result from nutrient-loading and associated eutrophication 
(Kinsey \& Domm 1974, Pastorok \& Bilyard 1985, LaPointe \& O'Connell 1989) does not occur. Consistent with the findings of Szmant \& Forrester (1996), we infer that the inward advection of inorganic nutrients is not a dominant forcing mechanism for benthic biogeochemical function in our study region. In fact, based on our determination of a holistic $P / R$ ratio less than 1 , we infer that the carbonate platform of the NFRT is a sink for external inputs of particulate organic matter.

The NFRT segment investigated demonstrates a holistic carbon and carbonate metabolism that most closely resembles that of coastal reef systems that receive elevated influxes of organic detritus (Kinsey 1988). Inorganic nutrient loading typically affects reef communities by enhancing primary production, but sewage-rich sediment pollution promotes filter-feeding heterotrophy, and leads to boring and dissolution of the reef substratum (Smith et al. 1981, Kinsey 1988). Although suspended sediment in high concentrations is a known stressor for coral reefs (Hubbard 1986, Abdel-Salam \& Porter 1988, Te 1992, Riegl \& Branch 1995), some corals utilize sediment as a supplementary food source (Riegl et al. 1996, Rosenfeld et al. 1999).

The sewage pollution of Kaneohe Bay, Hawaii from the 1950 s to the $1970 \mathrm{~s}$ is an excellent example of the impact of organic detritus-rich suspended particulate loading on a nearshore reef system adjacent to heavy urbanization. Sewage created a soluble nutrient input that stimulated a supply of water column phytoplankton and zooplankton, and resulted in a flux of organic particulates to southern Kaneohe Bay that rivaled or exceeded inorganic nutrient loading (Kinsey 1988). Benthic detritivorous heterotrophic biomass increased markedly, and the cycling of nutrients between heterotrophs, autotrophs, detritus, and inorganic nutrients became quite active (Smith et al. 1981). Moreover, benthic primary production decreased, particle-feeding epifauna and infauna and community respiration greatly increased, and calcification declined. Colonization by coral and algal communities was thereby replaced by filter feeding communities largely composed of zooanthids, sponges, and barnacles (Kinsey 1988). We suggest that the degradation of the NFRT has affinities with the mode of phase shifts that have occurred in Kaneohe Bay and other reef systems polluted by organic detritus.

The high respiration rates observed on the study region patch reefs may be due to both coral trophic elasticity and changes in community composition as an adaptation to increasing suspended particulate matter concentration (Johannes 1974). Corals derive nourishment from their zooxanthellae and also from feeding on zooplankton, detritus, and bacteria. This capability for trophic elasticity allows accommodation to varying light levels, nutrients, and particle loads, and varies between coral species (Johannes 1974, Porter 1974, Anthony \& Fabricius 2000). The ability of a coral species to shift trophic mode in response to variations in suspended particulate loading and shading is a means of expanding the inhabitable physiological niche (Anthony \& Fabricius 2000).

The zooxanthellate reef-building corals Montastrea annularis, Stylophora pistillata, Meandrina meandrites, Goniastrea retiformis, and Porites cylindrical have been shown to feed on suspended particulate matter to compliment or replace autotrophic nutrition (Tomascik \& Sander 1985, Telesnicki \& Goldberg 1995, Ferrier-Pages at al. 1998, Anthony \& Fabricius 2000). Heterotrophic nutrition takes place routinely in scleractinian corals, even if light is sufficient for the satisfaction of metabolic carbon requirements by photosynthesis, because symbiotic algae do not provide all of the needed nutrients to the host coral (Dubinsky \& Jokiel 1994, Rosenfeld et al. 1999).

The trophic environment of photosymbiotic aquatic organisms such as scleractinian corals can be altered by increased concentration of water column suspended particulate matter, a likely occurrence in the NFRT over the last several decades. The maintenance of a positive energy balance in photosymbiotic benthic suspension feeders may require heterotrophic as well as phototrophic acclimation at sites of elevated suspended organic and inorganic sediment concentration (Anthony \& Fabricius 2000). Indeed, under lightlimiting turbid conditions, particulate feeding may supply most of the energy needed by corals (FerrierPages et al. 1998, Anthony \& Fabricius 2000). Experiments using fluorescently labeled sediment have demonstrated that in such turbid environments, corals consume and digest the organic matter fraction of suspended sediment (Rosenfeld et al. 1999). Consistent with the numerous studies that describe the deleterious impacts of sediment, above a threshold in concentration, suspended particulates can smother corals and reduce zooxanthellae photosynthesis and coral growth rates by reducing light (Tomascik \& Sander 1985, Anthony \& Fabricius 2000). We propose that the possibility of heterotrophic functioning of scleractinian corals in the NFRT be investigated as a possible response to suspended particulate loading.

Under conditions of increasing suspended sediment eutrophication in reef systems, some reef benthos have a competitive edge over other reef organisms in that they can more readily act as heterotrophs (Bak et al. 1998). This suggests another possible explanation for the high respiration rates observed on NFRT patch reefs, that is, a past community shift towards increased abundance of octocorals and suspension feeders. Presently these reefs are covered with gorgonian octocorals, and although the ability of gorgonians to feed 
on the organic fraction of suspended sediment has not been well documented, their morphology suggests that they have this capability (Rosenfeld et al. 1999). A slenderness ratio, the height to width ratio of the body plane normal to the flow, proposed by Abelson et al. (1993) can be used to evaluate the morphologies of benthic organisms. High slenderness ratio organisms such as gorgonians create diverging flow, causing higher fluxes of fine suspended particles to be encountered. The very high slenderness ratios of gorgonians, and the typical increase of low density organic particle flux with height above the seabed, strongly suggest that gorgonians are active feeders on suspended organic detritus (Abelson et al. 1993).

Studies of similar nearshore octocoral-dominated reefs in water with elevated turbidity due to suspended particulate matter loading have demonstrated the community capability to remove particulate organic carbon. Fabricius \& Dommisse (2000) found that reef communities in a high turbidity nearshore regime and dominated by zooxanthellate alcyonacean octocorals can extract large quantities of suspended particulate matter from the water column. Suspended sediment import greatly exceeded export, and therefore these alcyoniid octocoral-dominated nearshore reefs were determined to be net heterotrophic (Fabricius \& Dommisse 2000), as are the gorgonian octocoral-dominated patch reefs in our NFRT study region. Accordingly, future investigation is suggested on the ability of NFRT patch reef gorgonians to consume suspended particulate matter and thereby meet metabolic requirements, and establish high population densities on reefs with elevated turbidity.

\section{CONCLUSIONS}

This study demonstrates that biotope mapping by remote sensing combined with local metabolic functions determined by a large portable benthic incubation system enables the estimation of reef system excess organic carbon production and calcification at reef zone and biotope scales. AISA airborne hyperspectral scanning at $1.5 \mathrm{~m}$ spatial resolution is shown to be markedly superior to satellite multispectral imaging in the spatial scaling of benthic metabolic processes in coral reef ecosystems. The mapping limitations of the $15 \mathrm{~m}$ resolution ASTER multispectral satellite sensor resulted in respective errors in holistic excess production and calcification rates of 48 and $431 \%$ relative to estimates based on AISA hyperspectral scanning corrected by a map accuracy analysis. We judge these errors to be unacceptable, and accordingly, we cannot recommend that ASTER or similar spatial resolution multispectral satellite sensors be used to spatially scale reef system carbon and carbonate fluxes. The respective errors in holistic excess production and calcification rates determined based on $4 \mathrm{~m}$ resolution IKONOS multispectral satellite mapping are 19 and $125 \%$, much less than those obtained with ASTER.

The holistic calcification rate of $0.07 \mathrm{~g} \mathrm{CaCO}_{3} \mathrm{~m}^{-2} \mathrm{~d}^{-1}$ estimated by our scaling analysis for a segment of the backreef platform of the northern Florida reef tract is negligible. All substrates in this reef zone were determined to be net heterotrophic, resulting in an estimated holistic excess production rate of $-0.56 \mathrm{~g} \mathrm{C}$ $\mathrm{m}^{-2} \mathrm{~d}^{-1}$ and an overall $P / R$ ratio of 0.85 . The comparatively low overall study region rate of gross primary production of $3.1 \mathrm{~g} \mathrm{C} \mathrm{m}^{-2} \mathrm{~d}^{-1}$ is exceeded by a respiration rate of $3.7 \mathrm{~g} \mathrm{C} \mathrm{m}^{-2} \mathrm{~d}^{-1}$. Based on the observed heterotrophy, we infer that the inward advection of inorganic nutrients is not a dominant forcing mechanism for benthic biogeochemical function on the backreef platform of the northern Florida reef tract. Rather, we conclude that this reef zone is a sink for external inputs of particulate organic matter, and suggest that the degradation of the northern Florida reef tract may resemble phase shifts documented within other reef systems polluted by organic detritus. Our study has established a need for future investigation of possible heterotrophic functioning of scleractinian corals and gorgonian octocorals on NFRT patch reefs in response to suspended particulate loading.

Acknowledgements. The authors acknowledge R. Curry, S. Viehman, and T. Kellison of Biscayne National Park for providing a 'test bed' for the development of new techniques for coral reef assessment, and for their very significant efforts to aid our field investigations. J.C.B. thanks J. Lisle, P. Swarzenski, and I. Kuffner for their thoughtful and worthwhile reviews of an earlier version of this manuscript. The authors acknowledge the U.S. Geological Survey's Coastal and Marine Geology Program for funding their investigation of coral reef ecosystems.

\section{LITERATURE CITED}

Abdel-Salam HA, Porter JW (1988) Physiological effects of sediment rejection on photosynthesis and respiration in three Caribbean reef corals. Proc 6th Int Coral Reef Symp 2:285-291

Abelson A, Miloh T, Loya Y (1993) Flow patterns induced by substrata and body morphologies of benthic organisms, and their roles in determining availability of food particles. Limnol Oceanogr 38:1116-1124

Abrams, M (2000) The Advanced Spaceborne Thermal Emission and Reflection Radiometer (ASTER): data products for the high spatial resolution imager on NASA's Terra platform. Int J Remote Sens 21:847-859

Ahmad W, Neil DT (1994) An evaluation of Landsat Thematic Mapper (TM) digital data for discriminating coral reef zonation: Heron Reef (GBR). Int J Remote Sens 15: $2583-2597$ 
Andrefouet S, Payri C (2000) Scaling-up carbon and carbonate metabolism of coral reefs using in situ data and remote sensing. Coral Reefs 19:259-269

Andrefouet S, Claereboudt M, Matsakis P, Pages J, Dufour P (2001) Typology of atoll rims in Tuamotu Archipelago (French Polynesia) at landscape scale using SPOT HRV images. Int J Remote Sens 22:987-1004

Andrefouet S, Robinson JA, Hu CM, Feldman GC, Salvat B, Payri C, Muller-Karger FE (2003) Influence of the spatial resolution of SeaWiFS, Landsat-7, SPOT, and International Space Station data on estimates of landscape parameters of Pacific Ocean atolls. Can J Remote Sens 29: $210-218$

Anthony KRN, Fabricius KE (2000) Shifting roles of heterotrophy and autotrophy in coral energetics under varying turbidity. J Exp Mar Biol Ecol 252:221-253

Ault JS, Bohnsack JA, Meester GA (1998) A retrospective (1979-1996) multispecies assessment of coral reef fish stocks in the Florida Keys. Fish Bull 96:395-414

Ault JS, Smith SG, Meester GA, Luo J, Bohnsack JA (2001) Site characterization for Biscayne National Park: assessment of fisheries resources and habitats. NOAA Tech Memo NMFS-SEFSC-468

Bainbridge S, Reichelt R (1988) An assessment of ground truth methods for coral reef remote sensing data. Proc 6th Int Coral Reef Symp 2:439-444

Bak RPM, Joenje M, de Jong I, Lambrechts DYM, Nieuwland G (1998) Bacterial suspension feeding by coral reef benthic organisms. Mar Ecol Prog Ser 175:285-288

Bohnsack JA, Ault JS (1996) Management strategies to conserve marine diversity. Oceanography 9:73-82

Bouvet G, Ferraris J, Andrefouet S (2003) Evaluation of largescale unsupervised classification of New Caledonia reef ecosystems using Landsat 7 ETM+ imagery. Oceanol Acta 26:281-290

Boyer JN, Jones RD (2002) A view from the bridge: external and internal forces affecting the ambient water quality of the Florida Keys National Marine Sanctuary (FKNMS). In: Porter JW, Porter KG (eds) The Everglades, Florida Bay, and coral reefs of the Florida Keys. CRC Press, Boca Raton, FL, p 609-628

Brock JC, Wright CW, Clayton TD, Nayegandhi A (2004) LIDAR optical rugosity of coral reefs in Biscayne National Park, Florida. Coral Reefs 23:48-59

Brown BE (1988) Assessing environmental impacts on coral reefs. Proc 6th Int Coral Reef Symp 1:71-79

Burke L, Maidens J (2002) Reefs at risk in the Caribbean. World Resources Institute, Washington, DC

Burns TP (1985) Hard-coral distribution and cold-water disturbances in South Florida: variation with depth and location. Coral Reefs 4:117-124

Call KA, Hardy JT, Wallin DO (2003) Coral reef habitat discrimination using multivariate spectral analysis and satellite remote sensing. Int J Remote Sens 24:2627-2639

Capolsini P, Andrefouet S, Rion C, Payri C (2003) A comparison of Landsat ETM+, SPOT HRV, IKONOS, ASTER, and airborne MASTER data for coral reef habitat mapping in South Pacific islands. Can J Remote Sens 29:187-200

Catt P, Hopley D (1988) Assessment of large-scale photographic imagery for management and monitoring of the Great Barrier Reef. Symp Remote Sens Coastal Zone 3: $1-14$

Causey BD, Dodge ED, Jaap W, Banks K, Delaney J, Keller BD, Spieler R (2002a) Status of coral reefs in Florida. In: Turgeon DD (ed) The state of coral reef ecosystems of the United States and Pacific Freely Associated States: 2002. NOAA, Silver Spring, MD, p 101-118
Causey BD, Delaney J, Diaz E, Dodge D and 14 others (2002b) Status of coral reefs in the US Caribbean and Gulf of Mexico. In: Wilkinson C (ed) Status of coral reefs of the world: 2002. Australian Institute of Marine Science, Townsville, p 251-276

Christensen NL, Bartuska A, Brown JH, Carpenter S and 9 others (1996) The scientific basis for ecosystem management. Ecol Appl 6:665-691

Clark CD, Ripley HT, Green EP, Edwards AJ, Mumby PJ (1997) Mapping and measurement of tropical coastal environments with hyperspectral and high spatial resolution data. Int J Remote Sens 18:237-242

Cook CB, Mueller EM, Ferrier MD, Annis E (2002) The influence of nearshore waters on corals of the Florida Reef Tract. In: Porter JW, Porter KG (eds) The Everglades, Florida Bay, and coral reefs of the Florida Keys. CRC Press, Boca Raton, FL, p 771-788

Curry S, Schuckman K (1993) Practical considerations for the use of airborne GPS for photogrammetry. Photogram Eng Remote Sens 59:1611-1617

Done TJ (1992) Phase shifts in coral reef communities and their ecological significance. Hydrobiologia 247:121-132

Done TJ (1999) Coral community adaptability to environmental change at the scales of regions, reefs and reef zones. Am Zool 39:66-79

Dubinsky Z, Jokiel PL (1994) Ratio of energy and nutrient fluxes regulates symbiosis between zooxanthellae and corals. Pac Sci 48:313-324

Dubinsky Z, Stambler N (1996) Marine pollution and coral reefs. Global Change Biol 2:511-526

Dustan P, Chakrabarti S, Alling A (2000) Mapping and monitoring the health and vitality of coral reefs from satellite: a biospheric approach. Life Support and Biosphere Science. Int J Earth Space 7:149-159

Fabricius KE, Dommisse M (2000) Depletion of suspended particulate matter over coastal reef communities dominated by zooxanthellate soft corals. Mar Ecol Prog Ser 196: $157-167$

Ferrier-Pages C, Allemand D, Gattuso JP, Jaubert J (1998) Microheterotrophy in the zooxanthellate coral Stylophora pistillata: effects of light and ciliate density. Limnol Oceanog 43:1639-1648

Fowler R (2001) Topographic lidar. Digital elevation model technologies and applications. In: Maune DF (ed) Digital elevation model technologies and applications: the DEM users manual. Society of Photogrammetry and Remote Sensing, Bethesda, MD, p 207-236

Gattuso JP, Jaubert J (1990) Effect of light on oxygen and carbon-dioxide fluxes and on metabolic quotients measured in situ in a zooxanthellate coral. Limnol Oceanogr 35: 1796-1804

Gattuso JP, Frankignoulle M, Wollast R (1998) Carbon and carbonate metabolism in coastal aquatic ecosystems. Annu Rev Ecol Syst 29:405-434

Ginsburg RN, Shinn EA (1993) Preferential distribution of reefs in the Florida reef tract: The past is the key to the present. In: Ginsburg RN (ed) Proceedings of the Colloquium on Global Aspects of Coral Reefs: health, hazards, and history. University of Miami, FL, p H21-H26

Gordon HR (1978) Removal of atmospheric effects from satellite imagery of the oceans. Appl Optics 17:1631-1636

Gordon HR, Clark DK (1981) Clear water radiances for atmospheric correction of coastal zone color scanner imagery. Appl Optics 20:4175-4180

Green EP, Mumby PJ, Edwards AJ, Clark CD (1996) A review of remote sensing for the assessment and management of tropical coastal resources. Coast Manag 24:1-40 
Green EP, Mumby PJ, Edwards AJ, Clark CD (2000) Remote sensing handbook for tropical coastal management. UNESCO, Paris

Grigg RW, Dollar SJ (1990) Natural and anthropogenic disturbance on coral reefs. In: Dubinsky Z (ed) Ecosystems of the World, Vol 25. Coral Reefs. Elsevier, New York, p 439-452

Grigg RW, Polovina JJ, Atkinson MJ (1984) Model of a coral reef ecosystem 3 . Resource limitation, community regulation, fisheries yield and resource management. Coral Reefs 3:23-27

Gurney RJ, Foster JL, Parkinson CL (1993) Atlas of satellite observations related to global change. Cambridge University Press, Cambridge

Hallock P, Muller-Karger FE, Halas JC (1993) Coral reef decline. Natl Geogr Res 9:358-378

Hatcher BG (1990) Coral reef primary productivity: a hierarchy of pattern and process. Trends Ecol Evol 5:149-155

Hatcher BG (1997) Coral reef ecosystems: how much greater is the whole than the sum of the parts? Coral Reefs 16:S77-S91

Hatcher BG (1999) Organic production and decomposition. In: Birkeland C (ed) Life and death of coral reefs. Chapman \& Hall, New York, p 140-174

Haus BK, Wang JD, Rivera J, Martinez-Pedraja J, Smith N (2000) Remote radar measurement of shelf currents off Key Largo, Florida, USA. Estuar Coast Shelf Sci 51: 553-569

Held A, Ticehurst C, Lymburner L, Williams N (2003) Highresolution mapping of tropical mangrove ecosystems using hyperspectral and radar remote sensing. Int $\mathrm{J}$ Remote Sens 24:2739-2759

Hochberg EJ, Atkinson MJ (2000) Spectral discrimination of coral reef benthic communities. Coral Reefs 19:164-171

Hoegh-Guldberg O (1999) Climate change, coral bleaching and the future of the world's coral reefs. Mar Freshw Res 50:839-866

Hubbard DK (1986) Sedimentation as a control of reef development: St. Croix, USVI. Coral Reefs 5:117-125

Hudson JH (1981) Response of Montastrea annularis to environmental change in the Florida Keys. Proc 4th Int Coral Reef Symp 2:233-240

Hudson JH, Hanson KJ, Halley RB, Kindinger JL (1994) Environmental implications of growth rate changes in Montastrea annularis: Biscayne National Park, Florida. Bull Mar Sci 54:647-669

Hughes TP (1994) Catastrophes, phase shifts, and largescale degradation of a Caribbean coral reef. Science 265: $1547-1551$

Jaap WC (1984) The ecology of the south Florida coral reefs: a community profile. U.S. Fish and Wildlife Service FWS/OBS-82/08

Jaap WC, Porter JW, Wheaton J, Hackett K, Lybolt M, Callahan MK, Tsokos C, Yanev G (2001) EPA / FKNMS coral reef monitoring project updated executive summary 1996-2000: steering committee meeting August 1, 2001. Environmental Protection Agency, Washington, DC

Johannes RE (1974) Sources of nutritional energy for reef corals. Proc 2nd Int Coral Reef Symp 1:133-137

Jones JA (1963) Ecological studies of the southeastern Florida patch reefs. Part I. Diurnal and seasonal changes in the environment. Bull Mar Sci 13:282-307

Jones JA (1977) Morphology and development of southeastern Florida patch reefs. Proc 3rd Int Coral Reef Symp, p 232-235

Jones RD, Boyer JN (2001) Water quality protection program, Florida Keys National Marine Sanctuary. Water quality monitoring project FY2000 annual report. Florida International University Southeast Environmental Research Center Technical Report \#T151, Miami, FL

Joyce K, Phinn S (2003) Hyperspectral analysis of chlorophyll content and photosynthetic capacity of coral reef substrates. Limnol Oceanogr 48:489-496

Kinsey DW (1978) Alkalinity changes and coral reef calcification. Limnol Oceanogr 23:989-991

Kinsey DW (1983) Standards of performance in coral reef primary production and carbon turnover. In: Barnes DJ (ed) Perspectives on coral reefs. Brian Clouster Publishing, Manuka, p 209-220

Kinsey DW (1985) Metabolism, calcification and carbon production. I: Systems level studies. Proc 5th Int Coral Reef Congr 4:505-526

Kinsey DW (1988) Coral reef system response to some natural and anthropogenic stresses. Galaxea 7:113-128

Kinsey DW, Domm A (1974) Effects of fertilization on a coral reef environment - primary production studies. Proc 2nd Int Coral Reef Symp 1:49-56

Kleypas JA, Buddemeier RW, Archer D, Gattuso JP, Langdon C, Opdyke BN (1999) Geochemical consequences of increased atmospheric carbon-dioxide on coral reefs. Science 284:118-120

Krabill WB, Martin CF (1987) Aircraft positioning using global positioning system carrier phase data. Navigation: J Inst Nav 34:1-21

Krabill WB, Wright CW, Swift RN, Frederick EB and 7 others (2000) Airborne laser mapping of Assateague National Seashore beach. Photogram Eng Remote Sens 66:65-71

Kramer P (2003) Synthesis of coral reef health indicators of the western Atlantic: results of the AGRRA Program (1997-2000). In: Lang JC (ed) Status of coral reefs in the western Atlantic: results of initial surveys, Atlantic and Gulf Rapid Reef Assessment (AGRRA) program. Atoll Research Bulletin No. 496, National Museum of Natural History, Smithsonian Institution, Washington, DC

Lapointe BE, O'Connell JD (1989) Nutrient-enhanced growth of Cladophora prolifera in Harrington Sound, Bermuda: eutrophication of a confined, phosphorus-limited marine ecosystem. Estuar Coast Shelf Sci 28:347-360

Lapointe BE, Clark MW (1992) Nutrient inputs from the watershed and coastal eutrophication in the Florida Keys. Estuaries 15:465-476

Lapointe BE, Matzie WR, Clark MW (1993) Phosphorus inputs and eutrophication on the Florida reef tract. In: Ginsburg RN (ed) Proceedings of the Colloquium on Global Aspects of Coral Reefs: health, hazards, and history. University of Miami, FL, p 106-112

Lapointe BE, Matzie WR, Barile PJ (2002) Biotic phase-shifts in Florida Bay and fore reef communities of the Florida Keys: linkages with historical freshwater flows and nitrogen loading from Everglades runoff. In: Porter JW, Porter KG (eds) The Everglades, Florida Bay, and coral reefs of the Florida Keys. CRC Press, Boca Raton, FL, p 629-648

Lee T (1986) Coastal circulation in the Key Largo Coral Reef Marine Sanctuary. Physics of shallow estuaries and bays. Lecture notes on coastal and estuarine studies 16. Springer-Verlag, Berlin, p 178-198

Lubin D, Li W, Dustan P, Mazel CH, Stamnes K (2001) Spectral signatures of coral reefs: features from space. Remote Sens Environ 75:127-137

Malthus TJ, Mumby PJ (2003) Remote sensing of the coastal zone: an overview and priorities for future research. Int J Remote Sens 24:2805-2815

Marsh JA, Smith SV (1978) Productivity measurements of 
coral reefs in flowing water. UNESCO Monogr Oceanogr Methodol 5:361-378

Marszalek DS, Babashoff G, Jr, Noel MR, Worley DR (1977) Reef distribution in south Florida. Proc 3rd Int Coral Reef Symp 224-229

McPherson BF, Halley RB (1996) The south Florida environment: a region under stress. US Geological Survey Circular 1134, US Government Printing Office, Washington, DC

Mueller E, Peters EC, Porter JW, Porter KG (2001) Etiology and distribution of coral diseases in the Florida Keys National Marine Sanctuary. NOAA, Office of National Marine Sanctuaries, Key West, FL

Mumby PJ, Edwards AJ (2002) Mapping marine environments with IKONOS imagery: enhanced spatial resolution can deliver greater thematic accuracy. Remote Sens Environ 82:248-257

Mumby PJ, Green EP, Edwards AJ, Clark CD (1997a) Coral reef habitat mapping: how much detail can remote sensing provide? Mar Biol 130:193-202

Mumby PJ, Green EP, Edwards AJ, Clark CD (1997b) Measurement of seagrass standing crop using satellite and digital airborne remote sensing. Mar Ecol Prog Ser 159: 51-60

Mumby PJ, Green EP, Clark CD, Edwards AJ (1998) Digital analysis of multispectral airborne imagery of coral reefs. Coral Reefs 17:59-69

Mumby PJ, Chisholm JRM, Clark CD, Hedley JD, Jaubert J (2001) A bird's-eye view of the health of coral reefs. Nature 413:36

Pastorok RA, Bilyard GR (1985) Effects of sewage pollution on coral reef communities. Mar Ecol Prog Ser 21:175-189

Porter JW (1974) Zooplankton feeding by the Caribbean reefbuilding coral Montastrea cavernosa, Proc 2nd Int Coral Reef Symp 1:111-125

Porter JW, Lewis SK, Porter KG (1999) The effect of multiple stressors on the Florida Keys coral reef ecosystem: a landscape hypothesis and a physiological test. Limnol Oceanogr 44:941-949

Porter JW, Dustan P, Jaap WC, Patterson KL, Kosmynin V, Meier OW, Patterson, ME, Parsons, M (2001) Patterns of spread of coral disease in the Florida Keys. Hydrobiologia 460:1-24

Porter JW, Kosmynin V, Patterson KL, Porter KG and 13 others (2002) Detection of coral reef change by the Florida Keys coral reef monitoring project. In: Porter JW, Porter KG (eds) The Everglades, Florida Bay, and Coral Reefs of the Florida Keys. CRC Press, Boca Raton, FL, p 749-769

Riegl B, Branch GM (1995) Effects of sediment on the energy budgets of four scleractinian (Bourne 1900) and five alcyonacean (Lamouroux 1816) corals. J Exp Mar Biol Ecol 186:259-275

Riegl R, Heine C, Branch GM (1996) Function of funnelshaped coral growth in a high-sedimentation environment. Mar Ecol Prog Ser 145:87-93

Editorial responsibility: Charles Birkeland (Contributing Editor), Honolulu, Hawaii, USA
Rosenfeld M, Bresler V, Abelson A (1999) Sediment as a possible source of food for corals. Ecol Lett 2:345-348

Schwarz KP, Chapman MA, Cannon MW, Gong P (1993) An integrated INS GPS approach to the georeferencing of remotely-sensed data. Photogram Eng Remote Sens 59: 1667-1674

Shinn EA, Lidz BH, Kindinger JL, Hudson JH, Halley RB (1989) Reefs of Florida and the Dry Tortugas: a guide to the modern carbonate environments of the Florida Keys and the Dry Tortugas. International Geological Congress Field Trip Guidebook T176, American Geophysical Union, Washington, DC

Smith SV, Key GS (1975) Carbon-dioxide and metabolism in marine environments. Limnol Oceanogr 20:493-495

Smith SV, Kimmerer WJ, Laws EA, Brock RE, Walsh TW (1981) Kaneohe Bay sewage diversion experiment: perspectives on ecosystem responses to nutritional perturbation. Pac Sci 35(4):279-395

Space Imaging (2004) IKONOS imagery products and product guide. Space Imaging, Thornton, CO

Szmant AM, Forrester A (1996) Water column and sediment nitrogen and phosphorus distribution patterns in the Florida Keys, USA. Coral Reefs 15:21-41

Te FT (1992) Response to higher sediment loads by Pocillopora damicornis planulae. Coral Reefs 11:131-134

Telesnicki GJ, Goldberg WM (1995) Effects of turbidity on the photosynthesis and respiration of two south Florida reef coral species. Bull Mar Sci 57:527-538

Thamrongnawasawat T, Hopley D (1994) Digitized aerial photography for mapping and monitoring exposed coral reef component distributions: a new tool for small-scale reef management. In: Bellwood O, Choat $\mathrm{H}$, Saxena N (eds) PACON '94: The Sixth Pacific Congress on Marine Science and Technology. James Cook University, Townsville

Thomson AG, Fuller RM, Yates MG, Brown SL, Cox R, Wadsworth RA (2003) The use of airborne remote sensing for extensive mapping of intertidal sediments and salt marshes in eastern England. Int $\mathrm{J}$ Remote Sens 24: $2717-2737$

Tomascik T, Sander F (1985) Effects of eutrophication on reefbuilding corals. I. Growth rate of the reef-building coral Montastrea annularis. Mar Biol 87:143-155

Wilkinson C (1992) Coral reefs of the world are facing widespread devastation: can we prevent this through sustainable management practices? Proc 7th Int Coral Reef Symp 1:11-21

Wright WC, Brock JC (2002) EAARL: a lidar for mapping shallow coral reefs and other coastal environments. In: Proceedings Seventh International Conference on Remote Sensing for Marine and Coastal Environments. Veridian International Conferences, Ann Arbor (CD-Rom)

Yates KK, Halley RB (2003) Measuring coral reef community and metabolism using new benthic chamber technology. Coral Reefs 22:247-255

Submitted: October 4, 2004; Accepted: November 23, 2005 Proofs received from author(s): March 28, 2006 